\title{
A THEORETICAL GROUNDING AND TEST OF THE GEM MODEL
}

Jonathan Levie*

Hunter Centre for Entrepreneurship

University of Strathclyde

Level 14, Livingstone Tower

Richmond Street, Glasgow G1 1XH

United Kingdom

Tel: (44) 1415483482

Fax: (44) 1415527602

Email: j.levie@strath.ac.uk

Erkko Autio*

Imperial College London

Tanaka Business School

Exhibition Road, London SW7 2AZ

United Kingdom

erkko.autio@imperial.ac.uk

Key Words: Entrepreneurial Activity, Entrepreneurial Framework Conditions

Subject Classification Numbers: L26, L53, O43

\begin{abstract}
The Global Entrepreneurship Monitor model combines insights on the allocation of effort into entrepreneurship at the national (adult working age population) level with literature in the Austrian tradition. The model suggests that the relationship between national-level new business activity and the institutional environment, or Entrepreneurial Framework Conditions, is mediated by opportunity perception and the perception of start-up skills in the population. We provide a theory-grounded examination of this model and test the effect of one EFC, education and training for entrepreneurship, on the allocation of effort into new business activity. We find that in high-income countries, opportunity perception mediates fully the relationship between the level of post-secondary entrepreneurship education and training in a country and its rate of new business activity, including high-growth expectation new business activity. The mediating effect of skills perception is weaker. This result accords with the Kirznerian concept of alertness to opportunity stimulating action.
\end{abstract}

*Both authors contributed equally to the development of this article. They are grateful to Paul Reynolds, David Audretsch and Zoltan Acs and to participants in the 2007 GEM Research Conference, Washington, DC for their encouragement and comments. This paper has been accepted for publication in Small Business Economics, October 2008 issue. 


\section{Introduction}

The Global Entrepreneurship Monitor (GEM) model, first published in Reynolds et al. (1999), proposes relationships between established and new business activity and economic growth at the national level. It also proposes antecedents of these two forms of business activity. The GEM model is influential because it affects how data is collected and analysed by the GEM consortium. To date, the relationships between the variables in the model have lacked explicit theoretical grounding. Because of this, the potential value of the GEM model for academic research remains unfulfilled, and it has been difficult to assess the value of empirical contributions based on GEM data. In this article, we relate the GEM model to influential theoretical frameworks in entrepreneurship. By discussing the GEM model in the light of received theory, we make it easier to assess the empirical contributions derived using the GEM model ${ }^{1}$. We also test one set of relationships embedded in the GEM model, that is, the relationships between national levels of entrepreneurship education and training, opportunity and skills perception in national populations, and types of national-level entrepreneurial activity.

The GEM model maintains that established business activity at the national level varies with General National Framework Conditions (GNFCs), while new, or entrepreneurial, business activity varies with national levels of Entrepreneurial Opportunity and Entrepreneurial Capacity. These, in turn, vary with Entrepreneurial Framework Conditions (EFCs) (Reynolds et al., 2005). The GEM model is a multi-level model, in that EFCs are described at the national level, while entrepreneurial opportunity, capacity and activity are measured at the individual level and aggregated to the national level. Thus, the model implies that entrepreneurial activity at the individual and national levels may respond to a different set of environmental parameters than established business activity. The GEM model does not seek to associate individual-level characteristics to individual-level entrepreneurial behaviours, but rather, it focuses on structural conditions that regulate the allocation of effort into entrepreneurship at the population level. The model also implies that, controlling for GNFCs, governments that ensure superior EFCs should expect higher national rates of entrepreneurial activity - and higher rates of economic growth.

\footnotetext{
${ }^{1}$ Note that we are not suggesting that the GEM model would constitute a 'theory' in its own right. To provide for meaningful interpretation of the GEM data, it is nevertheless important to discuss how the model relates to influential schools of thought within the domain of entrepreneurship.
} 
The GEM model assumes positive (if indirect) associations between EFCs and entrepreneurial activity. However, thus far, it has been unclear how these associations resonate with received theoretical frameworks in entrepreneurship, and the primary use of the model has been to guide data collection efforts. Previous explorations of the associations between EFCs and entrepreneurial activity have reported mainly negative bivariate correlations with early stage entrepreneurial activity (TEA) at the national level (Reynolds et al., 2002), and neutral or positive correlations with indicators of high-growth expectation entrepreneurial activity (HEA) (Autio, 2005; Autio, 2007). More positive and significant bivariate associations have been found with measures of the relative prevalence of high-growth expectation entrepreneurial activity, that is, HEA as a proportion of TEA (Autio, 2005; Autio, 2007). However, these cross-sectional data and bivariate correlation analyses have not provided rigorous tests of the association between EFCs and entrepreneurial activity.

In this article, we test one set of relationships embedded in the GEM conceptual model, that is, the relationships between entrepreneurship education and training, opportunity and capacity perception, and types of national-level entrepreneurial activity. Although EFC data based on national expert surveys has been collected each year since GEM started, empirical studies of the relationships between EFCs and types of entrepreneurial activity remain surprisingly rare. Furthermore, the few studies in existence have applied cross-sectional designs and have been the subject of obvious consequent limitations. Prompted by recent suggestions that high-growth expectation entrepreneurial activity may respond to EFCs differently from early-stage entrepreneurial activity as a whole (Autio, 2005, 2007), we compare associations between EFCs and both TEA and HEA. Aware of the complex relationship between the wealth of nations and new business activity rates (Acs et al., this issue; Minniti et al, 2006), we also test these relationships in a sample of high income nations.

We seek to make two important contributions in this paper. First, we build theory to lay out the relationships between EFCs and types of entrepreneurial activity, hence contributing to a firmer theoretical grounding of the GEM model. Second, employing seven-year panel data on the links between EFCs and GEM indices of national-level entrepreneurial activity, we provide the most 
extensive test of relationships specified by the GEM model that has been implemented thus far. In the following sections, we first build our theoretical model. We then explain our method and discuss our empirical findings. We conclude by suggesting implications for theory, and for further research.

\section{Linking the GEM model to theories of entrepreneurship}

\subsection{The GEM model}

The GEM model was created by Paul Reynolds based on an idea by Michael Hay in 1997 for a World Enterprise Index that would be the equivalent for enterprise and entrepreneurship of IMD's World Competitiveness Yearbook and the World Economic Forum's Global Competitiveness Index. Reynolds wished to "provide something that complemented the Global Competitiveness Model, which was implied more than explicated in the reports produced by the World Economic Forum at the time. An alternative to thinking that only large established firms were important; reflecting, as it were, the central contribution of David Birch to understanding business dynamics" (Reynolds, 2008). We reproduce the GEM model as shown in Acs et al. (2005) in Figure $1^{1}$. As this model is rather complex, we reserve the use of italics to denote elements of the GEM model throughout this paper.

Insert Figure 1 here

The GEM model describes two distinct business processes and proposes that they are associated with economic growth. The first process describes existing or routine business activity and its antecedents. We will not consider it further here, except to note that certain factors, extensively reported on by the World Economic Forum (WEF), are held to be directly associated with the level of general business activity (Lopez-Claros et al., 2006). The GEM model labels these factors General National Framework Conditions (GNFCs). GEM proposes an additional, complementary process in which individuals perceive opportunities and are thereby prompted to create new business activity, which in turn is proposed to impact economic growth. In so doing, the model follows theorists of entrepreneurship in the Austrian tradition, including Schumpeter (1934), and Kirzner (1997a), as well as other economists who have recognised the role of entrepreneurship in economic development, such as Leibenstein (1968), Baumol (2002) and Acs et al. 
(2004). GEM proposes that a second set of factors affects the level of new business activity, and these factors are termed Entrepreneurial Framework Conditions (EFCs).

On the left-hand side of the model, the backdrop to these two processes of creation of economic activity is what Leibenstein (1968) termed "socio-cultural and political constraints" (1968: 78). These constraints are labelled Social, Cultural, Political Context in the GEM model. They are underlying variables that would affect the way EFCs (and GNFCs) are constructed in a country. Examples might include national culture or universal values (Smith, Petersen and Schwartz, 2002), relative wealth, which would affect the ability of a government to deliver EFCs ${ }^{2}$, and type of government (for example, centralised planning versus open economy). Others might include population growth (Hunt and Levie, 2004; Levie and Hunt, 2005), and the growth rate of the economy itself (Acs and Amorós, this issue; Acs et al., 2005: 38; Lundström and Stevenson, 2005).

We turn now to the right hand side of the model, to the relationship between entrepreneurship and economic growth. Arguably the first economist to put the entrepreneur at centre stage of economic development was Schumpeter, who broke free from the prevailing comparative statics approach and recognised economies as self-transforming systems, with entrepreneurs as the agents of transformation (Schumpeter, 1934; Witt, 2002). To Schumpeter, entrepreneurs are innovators who open up profit-making opportunities by creating temporary monopolies through their organisational and technological innovations. They constantly disturb the status quo preferred by established incumbents, forcing these to react to emerging threats. This process of “creative destruction" (Schumpeter, 1947: 81) contributes to greater productivity, and hence, greater economic growth. This approach has been taken up and developed further by Leibenstein (1968), Baumol (2002) and others. Recently, Acs et al. (2004) have extended the new growth theory (Romer, 1990) by assigning an explicit role for the Schumpeterian entrepreneur as the converter of knowledge into economic knowledge, and thus, as a significant contributor to economic growth (see also Audretsch et al., 2006).

Schumpeter's entrepreneur disturbed economic equilibria through the act of innovating. An alternative perspective on entrepreneurship and economic growth was provided by subsequent 
Austrian economists, such as von Mises (1949), Hayek (1945, 1978) and Kirzner (1997b), who emphasised the role of entrepreneurs as discoverers of arbitrage opportunities in the market. Alert entrepreneurs stumble upon market disequilibria, as manifested in, for example, undervalued resources or unmet needs. This discovery gives rise to an equilibration process, as entrepreneurs seek to exploit their discoveries for economic benefit and thus generate economic growth. Rather than tending away from economic equilibrium, as in Schumpeter's model, this depiction portrays entrepreneurs as tending towards equilibrium (Baumol, 2003). This perspective treats entrepreneurship essentially as a market process and considers entrepreneurship to be an essential aspect of the human condition. Entrepreneurship is considered as human action "seen from the aspect of the uncertainty inherent in every action" (Mises 1949: 254); and "In any real and living economy every actor is always an entrepreneur" (Mises 1949: 253, cf Kirzner, 1997: 69). In this view, the essential question for entrepreneurship research is not who entrepreneurs are, but rather, what do they do, under which conditions, and with what consequences (Baumol, 1996; Murphy et al., 1991; Shane and Venkataraman, 2000).

Several writers have suggested that the Schumpeterian and Kirznerian views are complementary rather than contradictory (Baumol, 2003; Shane, 2003) and that both Schumpeterian and Kirznerian entrepreneurs contribute to economic growth. The GEM model accommodates this view $^{3}$ and includes both innovative, Schumpeterian entrepreneurs, and replicative arbitrageurs that make up the bulk of Kirznerian entrepreneurs. The typical Schumpeterian entrepreneur is rare and has a small chance of having a high impact on economic growth, while the Kirznerian entrepreneur is more common and has a better chance of having a low impact on economic growth. Given the greater quantity of Kirznerian entrepreneurs, however, their combined effect may be considerable, and they should not be ignored.

While the Austrian tradition has helped pinpoint essential conditions that give rise to entrepreneurship (i.e., innovation and discovery), its focus on the consequences of the entrepreneurial process has meant that it has not considered structural contingencies that might impact the allocation of effort to entrepreneurship. Helpful contributions in this regard have been made by Baumol (1990, 2003), and in parallel, Murphy et al. (1991), who focused explicitly on such contingencies. Baumol distinguished between productive, unproductive and destructive entrepre- 
neurship and proposed that the form of entrepreneurship an entrepreneur chooses is governed by the prevailing 'rules of the game', or the reward structure in the economy (Baumol, 1996). He recognised two conditions in particular as central to the process of allocation of effort into productive entrepreneurship: the degree to which the rule of law is respected in the country, and the degree to which laws support the appropriation of returns from entrepreneurial efforts.

Murphy et al. proposed a similar approach to Baumol, but focused on talent, arguing that: " $A$ country's most talented people typically organize production by others, so they can spread their ability advantage over a larger scale. When they start firms, they innovate and foster growth, but when they become rent seekers, they only redistribute wealth and reduce growth." (1991: 503). Murphy et al.'s analysis suggests that Baumol's general argument should apply also to highly talented individuals, who might be expected to engage in high potential entrepreneurship, assuming the opportunity costs are favourable.

We propose that it is helpful to think of the GEM model as an Austrian model of the 'Baumolian' allocation of effort into productive entrepreneurship ${ }^{4}$. This approach is reflected in GEM's main indicator of new business activity, the TEA index. The TEA index provides a measure of 'Baumolian' allocation of effort to entrepreneurship within a given population. This allocation is regulated by perception of opportunity within that population in the Austrian sense of that term. GEM's main contribution to the Baumolian analysis is a detailed consideration of 'Entrepreneurial Framework Conditions' (EFCs), or exogenous structural conditions that regulate the perception of opportunity and the availability of entrepreneurial skills in the population. To provide insight into the relationships between these structural conditions and entrepreneurial activity, we turn to Harvey Leibenstein $(1966 ; 1968 ; 1978 ; 1987 ; 1995)$, who has written extensively on this topic.

Like Schumpeter, Leibenstein (1968) recognised two broad types of business activity as contributing to economic growth: routine entrepreneurship or management, that is "the activities involved in coordinating and carrying on a well-established, going concern", and "new-type" or "N-entrepreneurship", that is "the activities necessary to create or carry on an enterprise where not all the markets are well established or clearly defined and/or in which the relevant parts of 
the production function are not completely known" (1968: 73 and 79). This distinction is also made in the GEM model. Established firm activity, represented by Major, Established Firms and Micro, Small and Medium Firms - the top row of the GEM model - is distinct from new entrepreneurial activity or New Firms - the bottom row of the model. Leibenstein linked the two activities to economic growth by suggesting that: “...growth would depend, in part, on the degree of routine entrepreneurship, the degree to which gaps and impediments in markets exist, and the quality, motivations, and opportunity costs of the potential gap-fillers and input-completers available.” (1968: 79)

This description mirrors the positioning of the GEM model variables of Entrepreneurial Opportunities, the "gaps and impediments in markets" (1968: 79) as the demand side of new firm creation and Entrepreneurial Capacity or "the capacity to assess such opportunities" (1968: 80) on the supply side. Leibenstein distinguished between the 'objective' "maximal productive possibilities set" (1968: 78) and the smaller 'subjective' set of opportunities that entrepreneurs perceive to exist. Kirzner (1979: 117), too, recognised that, "in principle", opportunities might be available without the entrepreneur. Shane and Venkataraman (2000) and Shane (2003) also take the view that opportunities exist independently of the observer, though they need human intervention to bring them to life. However, other theorists have questioned the objective existence of opportunities (see, for example, Gartner et al., 1992). Entrepreneurial Opportunities in the first iteration of the GEM model (Reynolds et al., 1999: 11) explicitly included both "existence" and "perception" of opportunities under this heading. This raises issues of operationalising existence of opportunities when, as Hayek, Kirzner and others have pointed out, information is widely distributed and not available to any one individual. We show in the methods section one way of dealing with this issue. Interestingly, Leibenstein saw perception of opportunity as an element of entrepreneurial capacity, based on skill and knowledge: "[only] those individuals who have the necessary skills to perceive entrepreneurial opportunities, to carry out the required input gapfilling activities, and to be input-completers can be entrepreneurs" (1978: 50).

In summary, the GEM model suggests that new business activity takes place when those who believe they have the skills, knowledge and motivation to start a business perceive an opportuni- 
ty to do so. Technical business start-up skills alone are not enough - an individual must perceive an opportunity before action can be taken.

In the GEM model, Entrepreneurial Capacity contains two of Leibenstein's three supply-side factors: "the set of individuals with gap-filling and input-completing capacities" (1968: 78) summarised as Skills in the GEM model, and "the degree to which potential entrepreneurs respond to different motivational states, especially where non-traditional activities are involved" (1968: 78-79), summarised as Motivation in the GEM model. As Leibenstein put it in a later paper: "What is necessary for the entrepreneur is a commitment to overcome difficulties whatever they may be in order to fully take advantage of an opportunity. Thus, motivation is a necessary element of entrepreneurship." (1987: 197) ${ }^{6}$

According to Leibenstein, "perception of economic opportunities and the capacity to assess such opportunities... are presumably determined in part by factors exogenous to the system such as those involved in nurture, informal training, experience, as well as formal education of individuals" (1968: 80). In an alternative but complementary conceptualisation, Acs et al. (2004) have proposed that economies have a "filter" that impedes the conversion of knowledge into economic knowledge, and the thickness of that filter, its mesh size, as it were, is a result of policy, traditions and path-dependence. In the GEM model, those exogenous factors that affect business activity generally, such as formal education, are labelled General National Framework Conditions, while those that are specific to the context of entrepreneurial activity, such as entrepreneurship training, are labelled Entrepreneurial Framework Conditions (EFCs).

\subsection{Entrepreneurial Framework Conditions}

Through the EFCs, the GEM model maps the specific conditions in which productive entrepreneurship, in the Baumolian (1996) sense, can flourish ${ }^{7}$. One could see EFCs as defining the rules

of the game for entrepreneurial activity in any given context: change the EFCs, and the rate and nature of (productive) entrepreneurial activity may change. Leibenstein set out the policy prospects for altering EFCs as follows: 
A Theoretical Grounding and Test of the GEM model

"While entrepreneurship may be scarce because of a lack of input completing capacities, some entrepreneurial characteristics may in fact be in surplus supply... ... unused simply because of the lack of the input completing capacity. ... it is possible that in some cases, small changes in the motivational state or in the reduction of market impediments may turn entrepreneurial scarcity into an abundant supply." (1968: 82)

In the following subsections, we consider each EFC in the GEM model and its possible effects on entrepreneurial activity, including examples of empirical findings to date.

\section{Finance}

Finance is arguably the most widely recognised regulator of allocation of effort to entrepreneurship. As a rule, some up-front investment is required to establish a new production function in the economy, creating an obvious need for financial investment in the expectation of subsequent returns. Finance was the only external regulator explicitly recognised by Schumpeter, who focused on the availability of bank credit, although he also mentioned private equity providers. It was clear to Schumpeter that entrepreneurship was more dependent than routine business activities on credit to fund access to resources: "credit is primarily necessary to new combinations" (Schumpeter, 1934: 70).

Leibenstein was well aware that capital was important to entrepreneurs, and that access to finance would vary by country. He observed that the sophistication of credit and lending systems varied across countries, and that entrepreneurs sometimes had to employ political strategies to get access to this vital resource: "In some countries the capacity to obtain finance may depend on family connections rather than on the willingness to pay a certain interest rate. A successful entrepreneur may, at times, have to have the capacity to operate well in the political arena connected with his economic activities" (1968: 73-74).

Access to finance is also the most widely recognised object of entrepreneurship policy, and insufficient finance is regularly cited by non-entrepreneurs as a barrier to starting a business (Volery et al., 1997; Kouriloff, 2000; Robertson et al., 2003; Choo and Wong, 2006). There is some evidence that restricted competition in banking and government credit controls can restrict entry 
in the non-financial sector (Cetorelli and Strahan, 2006; Kawai and Urata, 2002). In this regard, Leibenstein suggested that the return on an $\mathrm{N}$-entrepreneurial investment had different qualities to an investment in routine entrepreneurship, and that had implications for policy and for the financial industry (1968: 82).

It is clear then that the supply of finance for entrepreneurship should be considered in any model of structural conditions for entrepreneurship.

\section{Government Policy}

Government policy is recognised an explicit regulator of entrepreneurship in the GEM model. The inclusion of this EFC in the model reflects the broad policy interest toward entrepreneurship and the associated shift in emphasis from generic 'industrial policy' toward specific 'SME' and 'innovation' policies from the mid-1980s onwards (Storey, 1994; Storey and Tether, 1998). As such, however, the very existence of a distinctive 'entrepreneurship policy' remains a subject of ongoing debate. Some contend that entrepreneurship is too broad-based a phenomenon to be bracketed into a dedicated policy box (Acs and Szerb, 2007) while others make a case for exactly such bracketing (Lundström and Stevenson, 2005). Whether such bracketing is possible or not, there appears to be a general consensus that entrepreneurship is a phenomenon that can, at the national and regional levels, be addressed by policy-makers, and that increased awareness and attention by policy-makers should be positively associated with the allocation of effort into entrepreneurship (Audretsch et al., 2007). This view was shared by Leibenstein (1968:83), who recommended focusing on: “...the gaps, obstructions, and impediments in the market network of the economy in question and on the gap-filling and input-completing capacities and responsiveness to different motivational states of the potential entrepreneurs in the population." Policy, thus, should focus on enhancing the efficiency of the market, as well as on providing an environment that is responsive to motivated entrepreneurs.

Theoretical work emanating from the GEM research has emphasised the need of policy to be responsive not only to the needs and motivational states of entrepreneurs, but also to the general economic development in the country (van Stel et al., 2005; Wennekers et al., 2005; Acs et al., 2007). This body of work suggests that, for different economies, the optimal levels of entrepre- 
neurial activity may vary, and entrepreneurship, in general, may have different gap-filling functions in different stages of economic development. Because of such complexities, GEM's operationalization of the government policy EFC does not measure specific policies, but rather, focuses on the general prioritisation of entrepreneurship in government economic policy. Although this approach does not provide a clear policy prescription for Government, it does suggest that Government should take the need to facilitate entrepreneurs into account when designing and implementing policy. This sentiment is echoed by many supra-national organisations such as the OECD (Cotis, 2007) and the EU (Directorate-General Enterprise, 2004). Other writers in the Austrian tradition have tended to focus on one aspect of government policy: regulations.

\section{Government Regulations}

Governments can directly affect entrepreneurial firms through their regulatory controls. Kirzner $(1985,1997 a)$ in particular has shown that from an Austrian perspective, restriction of entry and exit inhibits the market process, thereby damaging economic growth. Regulations constitute one of the most widely studied external conditions for business and entrepreneurial activity, and regulatory issues are cited regularly in studies of barriers to start-ups that are based on surveys of non-entrepreneurs (Grilo and Irigoyen, 2006; van Stel et al., 2007). Some studies have found that regulations, taxes and labour market rigidities tend to load together in analyses of barriers to start-up (Volery et al., 1997; Choo and Wong, 2006; Klapper et al., 2006; Acs, Desai and Klapper, this issue).

Empirical studies suggest two ways in which regulations impact on the entrepreneurial process. First, cumbersome regulations and delays in obtaining the necessary permits and licenses may increase the duration of the start-up process (Klapper et al., 2006). This can reduce new business entry because the window of opportunity may have passed by the time all regulations are complied with. Regulations also enable officials to micro-manage industries by obstructing or delaying entry, either for personal or policy reasons (Maddy, 2000, 2004). Dreher and Gassebner (2007), for example, reported a negative relationship between the number of licenses and permits required for entry and new firm formation rate. Similarly, Van der Horst et al. (2000) found that regulatory policies on licensing influenced entrepreneurs' decisions to start business ventures. 
Second, unpredictable and strenuous application of regulations pushes up compliance costs, thereby increasing the cost of startup and negatively impacting profitability and the firms' ability to use their retained earnings to fuel growth. In this sense, regulations represent the tangible application of government policy, as felt in the immediate operating environment of entrepreneurial firms. A particularly important component of control is taxation, and there is evidence that correctly applied tax policies may provide incentives for innovation and growth of firms (Keuschnigg and Nielsen, 2002, 2004; Goldfarb and Henrekson, 2003; Puffer and McCarthy, 2001). More commonly reported findings focus on a negative relationship, as taxes impose a direct financial cost on firms, affecting their profitability and growth (Baumol, 1990; Davidsson and Henrekson, 2002; Van der Horst et al., 2000).

\section{Government Programmes}

In his discussion of exogenous factors, Leibenstein (1986: 80) recognised the role of "nurture" in building entrepreneurial capacity. Nurturing could be conducted by government agents through dedicated nurturing programmes, or professional services advisors, such as accountants, bankers, lawyers and business consultants (Fischer and Reuber, 2003; Clarysse and Bruneel, 2007). Through dedicated support programmes, governments can facilitate the operation of entrepreneurial firms by addressing gaps in their resource and competence needs - either on a subsidised basis or by correcting the failure of the market to cater to such needs. Governments may support entrepreneurial firms through programmes through which they provide subsidies, material, and informational support for new ventures (Dahles, 2005, Keuschnigg and Nielsen, 2001, 2002, 2004). Such programmes may reduce transaction costs for the firms (Shane, 2002) and contribute towards the human capital of entrepreneurs (Fayolle, 2000, Delmar and Shane, 2003).

\section{Education and Training}

Education and training for entrepreneurship has been one of the most widely studied and used means to encourage entrepreneurial activity. Entrepreneurship-specific training and education is expected to enhance the supply of entrepreneurship through three distinct mechanisms: First, through the provision of instrumental skills required to start-up and grow a new firm (Honig, 2004); second, through the enhanced cognitive ability of individuals to manage the complexities involved in opportunity recognition and assessment, as well as in the creation and growth of new organisations (DeTienne and Chandler, 2004); and third, through the cultural effect on students' 
attitudes and behavioural dispositions (Peterman and Kennedy, 2003). Liebenstein emphasised the instrumental aspect of education, noting that: “... training can do something to increase the supply of entrepreneurship. ... since entrepreneurship requires a combination of capacities, some of which may be vital gaps in carrying out the input-completing aspect of the entrepreneurial role, training can eliminate some of these gaps." (1968: 82)

Entrepreneurship education and training as an exogenous factor is different from general education, which is included in several GNFCs. The effect of entrepreneurship education and training will be discussed more in detail in the next section, where we develop six hypotheses on the effect of entrepreneurship education and training on the supply of entrepreneurship.

\section{R\&D Transfer}

While Kirzner (1997) saw market opportunities as an originator of entrepreneurial action, Schumpeter (1996) emphasised the important role of technological development as a driving force behind entrepreneurial opportunities. This argument has been developed further in the 'knowledge spill-over theory of entrepreneurship' (Acs et al., 2004; Acs, 2006; Acs et al., 2007), which represents an extension of, as well as a merger, between the 'Romerian' and 'Schumpeterian' models of economic growth. The knowledge spill-over theory argues that knowledge by itself is a necessary, but not sufficient, condition for economic growth. Not all inventions are automatically converted into innovations, and not all advances in research knowledge end up giving rise to commercialised, economically useful knowledge.

New knowledge is predominantly created in research institutions and in large firms. To contribute to the economy, research knowledge needs to be converted into economically useful knowledge, and inventions need to be converted into innovations. Acs et al. (2006) suggest that this conversion process can occur either through established incumbents (in which case the process will be regulated by their absorptive capacity) or through innovative entrepreneurial firms. According to their theory:

“ entrepreneurship becomes central to generating economic growth by serving as a conduit, albeit not the sole conduit, by which knowledge created by incumbent organizations spills over to agents who endogenously create a new organization.” (Acs et al., 2006: 12). 
Entrepreneurship plays an important role in facilitating the exploitation of knowledge spillovers, because new knowledge is characterised by greater uncertainty and asymmetry than other economic goods. Entrepreneurial alertness and discovery are therefore required to uncover valuable new knowledge and harness knowledge slack created by unused knowledge advances generated by incumbents (Acs and Varga, 2005). Consistent with this theory, the GEM model proposes that countries in which transfer of knowledge generated by $R \& D$ from labs to entrepreneurs is relatively quick and cheap should generate more innovative new businesses than those in which this process is costly or slow.

\section{Commercial and Legal Infrastructure}

Commercial and Legal Infrastructure comprises business services that are necessary for the management of entrepreneurial firms. Such services include availability of subcontractors, suppliers, consultants and legal, accounting, advertising, financial, telecommunication, internet and banking services. Professional or business services are helpful throughout the entrepreneurial process, particularly in the management and operation of the firms (Suzuki et al., 2002). Good availability of business services permits entrepreneurial firms to focus on their core business, thereby achieving efficiency and specialisation gains. Among the services needed during the firm formation process are legal services (Ruef, 2005). Where there is lack of legal services, this could pose an obstacle to entrepreneurship (Brenner, 1992). This may be particularly important for high potential firms, which may rapidly need to obtain limited liability status and negotiate often complex legal agreements with many stakeholders.

\section{Internal Market Openness}

Economists in the Austrian tradition recognise market dynamics and industry structure as a motivating factor in entrepreneurial activity (e.g. Leibenstein, 1968: 79, 1987: 201; Kirzner, 1997a: 47). Market and industry structure and firm entry have been widely studied in the industrial organisation and entrepreneurship literatures (Geroski, 1989, 1995; Klepper, 1996, 2002; Klepper and Sleeper, 2005). Scholars have theorised both market- and technology life cycle effects, predicting higher rates of new firm entry near the beginning of a market's life cycle, as demand and supply increase rapidly, possibly facilitated by high levels of certain types of innovative and 
spin-off activity (Malerba and Orsenigo, 1996; Acs and Audretsch, 1990, Carree and Thurik, 2000; Klepper, 2002). In early stages, new firm entry provides an important driving factor of market dynamism, but market dynamism, in itself, also opens opportunities for entry by entrepreneurial ventures. There thus exists a two-way relationship between new firm entry and market dynamism. The exogenous factor of market structure is included in the GEM model as Internal Market Openness, which contains two parts, Market Dynamics which focuses on the rapidity of market change and Market Openness which deals with ease of entry to a market.

\section{Access to Physical Infrastructure}

Physical infrastructure such as transportation, land or operating space, and communication facilities such as internet, telephone and postal services are vital for the successful operation of entrepreneurial activities and venture start-up and growth (Trulsson, 2002; Liao et al., 2001; Hansen and Sebora, 2003). To set up a business, one usually needs access to physical infrastructure such as office and operating space, equipment and basic utilities ${ }^{8}$. The availability of such utilities will encourage the start-up of new ventures (Carter et al., 1996; Dubini, 1989).

Accessing physical infrastructure can be seen as one of the inputs that the Leibensteinian entrepreneur must pull together in his or her role as economic "gap-filler" and an "input-completer". As he put it (1996: 75): "If six inputs are needed to bring to fruition a firm that produces a marketable product, it does no good to be able to marshal easily five of them." This factor is obviously even more important to high potential entrepreneurs than to lifestyle entrepreneurs who may be able to work from home. Access to physical infrastructure for entrepreneurs can vary widely from country to country. While it may be taken for granted in many high income countries, in others it can be a major issue (see e.g. Bitzenis and Nito, 2005).

\section{Social, Cultural Norms}

Culture is a commonly cited determinant of entrepreneurial behaviour (George and Zahra, 2002). Here, it is important to distinguish between general national culture or universal values, such as measured by Hofstede (1980), Schwartz (1994), Inglehart (1997), and House (1998) and context specific beliefs or attitudes towards entrepreneurship. A number of empirical studies have reported statistical associations of, e.g., Hofstede's (1980) scales of culture and entrepreneurial ac- 
tivities (Hayton et al., 2002; Hofstede et al., 2003; Uhlaner and Thurik, 2007), but the results of attempts to date to measure the effect of national culture on entrepreneurial activity using standard national culture measures and appropriate controls have been mixed (Spencer and Gomez, 2004; Levie and Hunt, 2005), reflecting recent findings on relationships between national cultural values and practices generally (Javidan et al., 2006). According to Smith et al., (2002: 204), "widely-shared beliefs in given societies may mediate between cultural values and enactment of specific behaviours", and this may explain these mixed findings. The GEM model distinguishes between national culture, labelled as Cultural Context, which is dealt with separately as a contextual factor, and Entrepreneurial Cultural and Social Norms, which covers context-specific beliefs about and attitudes towards entrepreneurship ${ }^{9}$, which is treated as an EFC.

Unlike universal values, context-specific beliefs about entrepreneurship and its legitimacy can change quite rapidly (Etzioni, 1987). At the individual level, the social desirability of entrepreneurial behaviours influences individual entrepreneurial intentions (Ajzen, 1991). Positive cultural dispositions toward self-initiative, independence, innovativeness and individual effort will likely impact the perception of desirability, and hence, allocation of effort into entrepreneurship. Negative attitudes towards entrepreneurship as a barrier to entrepreneurial activity have been studied in several countries, including Russia (Kaufmann et al., 1995) and Japan (Hawkins, 1993; Helms, 2003).

A related potential determinant of entrepreneurial motivations and actions is social legitimation (Etzioni, 1987) or national respect for entrepreneurship. National respect for entrepreneurs, as evidenced by peoples' attitudes toward those who have obtained personal wealth through entrepreneurial actions, as well as positive publicity and media on the topic, is likely to influence peoples' perceptions of the social desirability of entrepreneurial actions, and hence, their entrepreneurial motivations and intent. There is some empirical support for this from the GEM adult population surveys (Reynolds et al., 2003: 45; Levie and Hunt, 2005). 


\section{Education and Training and Allocation of Effort into Entrepreneurship}

While education is one of the most widely discussed and studied themes in the entrepreneurship literature, population-level evidence concerning the influence of entrepreneurship training and education on entrepreneurial activity is still lacking (Béchard and Grégoire, 2005). In this section we employ the GEM model to develop hypotheses on the effect of national-level entrepreneurship training and education on national-level entrepreneurial activity that are consistent with the literature on this topic. We propose that, consistent with the GEM model, entrepreneurship training and education impacts national-level entrepreneurial activity through two main mechanisms ${ }^{10}$. One of these operates through its influence on the population's ability to recognise and pursue entrepreneurial economic opportunities. As the second mechanism, we contend that entrepreneurship training also infuses individuals with the necessary technical skills and competencies required to launch new start-up firms.

\subsection{Education, Opportunity Recognition, and Entrepreneurial Activity}

For nascent ventures, the entrepreneur's human capital, as expressed in her education, experience, and skills, constitutes arguably the most important initial resource endowment (Shrader and Siegel, 2007; Wright et al., 2007). Education enhances an individual's cognitive ability, thereby enabling her to better recognise an opportunity when one presents itself (DeTienne and Chandler, 2004; Parker, 2006). A key notion in mainstream entrepreneurship theories is that opportunities are discovered when the entrepreneur identifies a match between the world she observes and her unique skills, capabilities, and social capital (Eckhardt and Shane, 2003; Shane, 2000). Rather than search, Austrians argue, entrepreneurs speculate, take risks and discover (Hayek, 1945; Kirzner, 1997b). During this process, entrepreneurs constantly interact with customers and competing suppliers, thereby generating “...such facts as, without resort to [the competitive process] would not be known to anyone" (Hayek, 1978: 179 cf. Kirzner 1997b). This process of search and discovery places important demands on entrepreneurs' cognitive abilities.

Shane and Venkataraman (2000: 222) maintain that individuals' ability to recognise opportunities is dependent on: "(1) the possession of the prior information necessary to identify an oppor- 
tunity and (2) the cognitive properties necessary to value it". By prior information they mean experience-based understanding of user needs in a given domain. By cognitive properties they mean an individual's ability to process information emanating from social interactions that take place in the market. Whether the entrepreneur will be able to see the opportunity in any given situation will depend on her ability to comprehend, analyse, and make sense of the feedback received, as well as on her ability to translate this information into the economic language of supply and demand. Significant cognitive processing is required before serendipitous feedback emanating from social and economic interactions is converted into an action-enabling and actionguiding understanding of how to take advantage of a given situation, resource, or gap discovered in the marketplace.

Entrepreneurship training and education enhances the cognitive abilities required for the discovery of market opportunities (DeTienne and Chandler, 2004). Entrepreneurship training and education exposes individuals to stories and cases of the discovery and exploitation of entrepreneurial opportunities, thus providing students with examples that they can relate to when encountering market gaps and undervalued resources. Such examples endow students with an understanding of what is possible and what is feasible, making students both more alert to opportunities as well as more able to tangibly assess opportunities (Fiet, 2000). The financial component of entrepreneurship training and education endows students with an ability to quickly assess the feasibility of opportunities encountered, enabling them to relate the opportunity to their own situation. Because of these cognitive effects, entrepreneurship training and education should enhance opportunity discovery.

Hypothesis 1 At the national level, the perception of opportunity is positively associated with the quality of entrepreneurship training and education in a country's educational institutions.

Perception of opportunity is a key condition for entrepreneurial action (Corbett, 2005; Shane and Venkataraman, 2000). The situational character of the process of opportunity discovery further emphasises the gate-keeping role of opportunity discovery for entrepreneurial action. This aspect 
is also widely recognised in the entrepreneurship literature (Ardichvili et al., 2003). Therefore, we hypothesise:

Hypothesis 2 At the national level, the allocation of effort into entrepreneurship is positively associated with the perception of opportunity .

The above discussion implies a mediating relationship between entrepreneurship training and education, opportunity perception, and the allocation of effort into entrepreneurship. It is argued that entrepreneurship education exercises the strongest influence on the ability of individuals in a population to perceive opportunities and subsequently to act entrepreneurially. Therefore, we propose:

Hypothesis 3 At the national level, the influence of entrepreneurship training and education on allocation of effort into entrepreneurship is fully mediated by its influence on the perception of opportunity.

\subsection{Education, Skills and Entrepreneurial Activity}

As Schumpeter (1947b) observed, an entrepreneur is distinguished from an inventor in that an entrepreneur gets things done. Getting things done requires a special, rather than a specialist, set of skills, one distinguished by its generalist and broad-based nature (Lazear, 2004; Michelacci, 2003). Entrepreneurs need to master not only their own technical specialisation, but also a broad set of business management and leadership skills in order to access and mobilise the resources necessary for launching and growing the new venture. In other words, to successfully manage and orchestrate multiple domains of activity, entrepreneurs need to be 'jacks of all trades', who combine both domain-specific as well as generic management skills (Lazear, 2005). We argue, consistent with much of the literature on entrepreneurial pedagogy, that this broad-based skill set constitutes a distinctive aspect of the entrepreneurial process, and that the possession of entrepreneurial skills constitutes an important determinant of the allocation of effort into entrepreneurship (Boyd and Vozikis, 1994). Summarising, we hypothesise: 
Hypothesis 4 At the national level, the allocation of effort into entrepreneurship will be positively associated with the prevalence of entrepreneurial skills in the population.

This 'jack of all trades' skills profile required of entrepreneurs places important demands upon the education and training of potential new entrepreneurs (Heinonen and Poikkijoki, 2006; Levie, 2006). Most education programmes, particularly at higher levels of education, tend to focus on a single technical domain or on a given specialist profession (Bertrand, 1995). Researchers of entrepreneurship education and training often point out that highly specialised education programmes are ill suited to provide the broad-based and practice-oriented training required to teach entrepreneurial skills (Aronsson, 2004; DeTienne and Chandler, 2004; Garavan and O'Cinneide, 1994). Instead of teaching specialist technical skills, the training programmes aimed at enhancing entrepreneurial potential need to be highly practice-oriented, address a broad set of management, leadership, and organising skills and emphasise discovery-driven and contingency approaches to business planning (Honig, 2004; Levie, 2006). While many of the generalist skills required are likely picked up during the normal course of career progression, we argue that, because of the distinctive aspects of the entrepreneurial skill-set, national-level provision of entrepreneurship training and education in educational institutions will enhance entrepreneurial skills in the population: The possession of this broad skill set will infuse individuals with an entrepreneurial selfefficacy, which will prompt them to pursue entrepreneurial opportunities, once such have been discovered (Chen et al., 1998; Peterman and Kennedy, 2003). Therefore, we propose:

Hypothesis 5 At the national level, the prevalence of entrepreneurial skills within the population will be positively associated with the provision of entrepreneurship training and education in educational institutions.

As in the case of opportunity perception, we expect a mediating relationship between entrepreneurship training and education, entrepreneurial skills, and the allocation of effort into entrepreneurship: 
Hypothesis 6 At the national level, the influence of entrepreneurship training and education on the allocation of effort into entrepreneurship is mediated by its influence on the prevalence of entrepreneurial skills within the population.

\section{Method}

\subsection{Dataset}

To test the hypotheses, we employed seven years of country-level panel data from the Global Entrepreneurship Monitor (GEM) research consortium's database, covering the years 2000 to 2006. This panel consisted of annual country-level measures, computed as weighted national averages of responses to over 800,000 adult-population interviews and, in a separate survey, over 1,000 interviews with experts in specific aspects of the environment for entrepreneurship in the participating countries. The two surveys were carried out annually in each participating country. The data was grouped by year and country, and the dataset contained a total of 222 year-country observations in 48 countries. The number of panel observations per country varied from 1 to 7 , the average being 4.7. The dataset contained 147 year-country observations in 27 high income countries (countries with incomes greater than US\$20,000) and 77 observations in 22 middle and low income countries ${ }^{11}$.

At least 2000 random interviews (in most countries by telephone, but in some countries by doorto-door interviews based on sophisticated randomization procedures) were carried out for the adult population survey. All primary data from adult-population interviews were weighted based on relevant demographic variables so as to ensure that the data was as fully representative of a given country's adult-age population as possible (for a detailed account of the GEM method, see Reynolds et al., 2005).

The national expert survey employed a lengthy questionnaire with multiple items per EFC, reproduced in Appendix 1, which enabled country experts to assess each of the EFCs detailed in section 2. The selection of experts was carried out by GEM's national teams. To ensure balance of perspectives, the national teams were instructed to select at least four experts deemed particu- 
larly knowledgeable in each of the nine EFCs. With at least four experts per EFC, this selection strategy was designed to produce at least 36 respondents per country each year. Of the four experts per EFC, at least one was required to be an active entrepreneur. The remaining three experts per EFC were selected from among entrepreneurship academics, government policymakers, and providers of public and private services to entrepreneurs, for example venture capitalists. Once contacted with a detailed explanation of the project, virtually all national experts typically agreed to participate in the survey or interview.

The expert responses were combined into multi-item scales for each EFC. For example, the $\mathrm{Fi}$ nance EFC index was created from the experts responses to items A01 to A06 in the table in Appendix 1 on a 5 point Likert scale (where "completely true" = 1 and "completely false" = 5). Factor analysis was used to check that all factor items loaded on a single scale and that no important cross-loadings existed for individual items. As a result, three of the original EFCs, Government Policies, Education and Training, and Market Openness, were found to have 2 separate components. These are described in the next sub-section. Factor loadings of individual scale items were used as weights when computing the resulting multi-item scale. Between 2000 and 2006, some EFC items were refined at each annual GEM planning meeting to enhance internal reliability of the multi-item scales, although almost all scales featured good reliability (Chronbach alpha) of 0.7 or greater throughout this period. The internal reliabilities (Cronbach alpha) of the multi-item scales employed in 2006 range from a low of 0.76 to a high of 0.94 . Validity checks with proxies from secondary sources suggest good external validity for the scales employed. A detailed account of GEM's expert survey method is provided in Reynolds et al. (2005).

\subsection{Variables}

GEM identifies three types of entrepreneurs. Nascent entrepreneurs are individuals who are in the process of trying to start a firm and have done something tangible during the 12 months preceding the interview to this end. The individual concerned would plan to become an active owner-manager of the start-up, which must not have paid salaries to anyone for more than 3 months. New (or early-stage) entrepreneurs are owner-managers of entrepreneurial start-ups, as defined above, which have been in existence for more than 3 months but less than 42 months. 
Established entrepreneurs are owner-managers of entrepreneurial firms which have been in existence for at least 42 months. In terms of the GEM model, nascent and new entrepreneurs engage in new business activity (at the bottom end of the model in Figure 1) and established entrepreneurs engage in established business activity (top end of the model). Note that these individuals may be starting or running new businesses that are either independent or part-owned by an existing company; the defining condition is that they both manage and own, in whole or in part, the business. In this way, the entrepreneurial activity measures include "corporate entrepreneurs" with stakes in corporate ventures sponsored by established businesses. This inclusive approach is in line with both the Shumpeterian view of entrepreneurship (Schumpeter, 1934: 74-75) and that of Shane (2003: 224), although it goes beyond Baumol's “independent innovator" (2002: 55$)^{12}$.

We operationalized new business activity at the population level in three ways. Based on the pooled data of 808,000 GEM interviews, we computed the GEM Early-Stage Entrepreneurial Activity (TEA) index, labelled as TEA in our regression results, for each country-year. The TEA index indicates the percentage of the adult working-age population (18 to 64 years old) in a country who are classified as either nascent or new entrepreneurs, as defined above.

Because TEA incorporates any type of entrepreneurial activity (including self-employment attempts), the activity captured by this index includes both low-growth expectation and highgrowth expectation entrepreneurship. In the GEM data, nearly $50 \%$ of all start-up attempts do not expect to create any jobs within five years (Autio, 2007). Only some 10\% of all start-up attempts expect 20 or more jobs, and these start-up attempts are responsible for some $75 \%$ of the cohort's expected total number of jobs. Because of the skewness of the growth expectation distribution, we computed two more dependent variables. The High-growth Expectation TEA index, HEA, indicates the percentage of the adult working-age (18 to 64 years old) population who are classified as either nascent or new entrepreneurs, and who expect to create 20 or more jobs within five years $^{13}$. The HEA index captures the top $10 \%$ of the early-stage entrepreneurial population by growth expectation (or ambition).

The relative incidence of HEA varies across countries (Autio, 2007). The GEM 2007 Global Report on High-Growth Entrepreneurship suggests that in poorer countries in particular, early-stage 
entrepreneurial activity may be dominated more by low-growth expectation start-up attempts than in high-income countries. For this reason we computed the relative HEA index rHEA, which indicates the ratio between HEA and TEA: $($ rHEA = HEA / TEA). rHEA thus provides an indication of the anatomy, rather than population-level prevalence (or volume), of high-growth expectation entrepreneurship.

Our education predictor variables (and all other EFC variables, here employed as control variables) were derived from GEM's national expert survey. These variables are standardized scales based on responses to multiple items as described in the previous subsection and listed in Appendix 1. Excluding Education and Training, the EFC variables are presented in the regression in the customary GEM order, with the following labels:

Financial: Finance EFC

Government Policies

Government Policies: Policy EFC

Government Regulations: Regulations EFC

Government Programs: dropped due to high collinearity

R\&D Transfer: dropped due to high collinearity

Commercial, Legal Infrastructure: Business services EFC

Internal Market Openness

Market Dynamics: Market dynamism EFC

Market Openness: dropped due to high collinearity

Access to Physical Infrastructure: Physical infra EFC

Cultural, Social Norms: Entrep culture EFC

The Education and Training EFC is presented separately, and is measured with two variables:

Primary and Secondary level Education and Training: Primary education EFC Post-secondary level Education and Training: Higher education EFC

Our measures of Entrepreneurial Opportunity and Entrepreneurial Capacity were taken from two GEM adult population survey items asked of all respondents. Perception of opportunity, labelled Opportunity perception, was measured as the percentage of working age adults that ex- 
pressed an opinion and agreed with the statement: "In the next six months, there will be good opportunities for starting a business in the area where I live". Perception of capacity, labelled Start-up skills, was measured as the percentage of working age adults who expressed an opinion and agreed with the statement: "I have the skills, knowledge and experience required to start a business".

We also used a number of control variables, representing the Social, Cultural and Political Context in the GEM model. As discussed in the previous section, it has been shown that a country's wealth has a significant effect on the opportunities available (Shane, 2003: 147) and its entrepreneurial activity (e.g., Acs et al., this issue; van Stel et al., 2005). Therefore we controlled for the country's GDP per capita (purchasing power parity), measured as current US dollars per capita, and labelled GDP per cap ( $p p p$ ). This data was obtained from the IMF database ${ }^{14}$. We also introduced a grand mean -centred and squared term of the GDP per capita variable into the equation to capture any curvilinear effects, labelled GDP per cap (squared). A country's rate of population growth is likely to impact opportunities through increased demand for goods and services (Shane, 2003: 32). We therefore controlled for population growth rate, obtained from the IMF database and labelled Population Growth. A country's general economic conditions will impact the presence of economic and start-up opportunities. We therefore controlled also the country's GDP growth from previous year to present year, measured in current national currency and labelled GDP change. Also this data was obtained from the IMF database. Finally, we controlled for year effects (not shown in the tables, but data available on request).

The GEM model predicts that a country's General National Framework Conditions (GNFC) will affect its level of entrepreneurial activity, by influencing the nature of EFCs. As a proxy of the country's GNFC and general economic competitiveness, we used the country's Global Competitiveness Index (GCI) score, as computed by the World Economic Forum. Because the GCI index has been modified over the years, we used only those years for which a standardised form exists. The GCI score of 2003 was used for years 2000 - 2003, and the 2006 score was used for years 2004 - 2006. However, we decided to drop this control because of its high correlation with GDP per capita (>0.8). This did not affect our findings. 
Industry structures vary among countries, impacting the size distributions of firm populations (Fisman and Saria-Allende, 2004). We therefore controlled for the adult-population population prevalence of established entrepreneurial firms in the economy, labelled as Estab. e-ship rate. This data was obtained from GEM's adult population surveys. Contemporaneous data was used for this variable in the equations.

In order to control the robustness of our regression analyses, we also employed alternative control variables. We ran the same regressions using Index of Economic Freedom indices for business freedom, trading freedom, and freedom from corruption, respectively. The IEF business freedom index measures the ease of starting a new firm in a given country, and it could be reasonably used as a proxy of GEM's EFC for regulations. The IEF trading freedom measures the ease with which it is to trade within a given country, as well as to engage in import and export activity. The corruption index measures the strength of corruption in a given country, providing a good proxy for its institutional stability, as well as the rule of law. These indices were used since they covered all of the participating GEM countries from 2000 to 2006, and they had not been changed during the period. Because of high correlations, specifically between the corruption index and GDP per capita, not all controls could be introduced simultaneously into the equations. In total, more than 30 alternative combinations were checked. The findings reported here appeared robust to altering specifications of control variables.

\subsection{Estimation Issues}

Our dataset consisted of unbalanced panel data with a broad and relatively short structure, with several predictor variables and relatively short time series (maximum seven years). Only a few countries are present in the panel for all years. Because our dependent variable was potentially autocorrelated, we used the Baltagi-Wu test to check for this possibility (Baltagi and Wu, 1999). Because the Baltagi-Wu test provides an appropriate statistic for unbalanced panel data, it is recommended instead of the more commonly used Durbin-Watson test, which may be sensitive to gaps in the panel structure. There are no exact critical values for the Baltagi-Wu test in the literature, but values "much smaller than 2 " are suggestive of the need to correct for serial autocorrelation (Kögel, 2004). In none of our regressions with the three dependent variables (TEA, HEA, 
and rHEA) did the Baltagi-Wu conflict with this threshold, and we therefore ran Generalised Least Squares models without controlling for serial autocorrelation in error terms.

We used the Hausman test to check whether a fixed- or random-effect specification should be used for the GLS panel regression. The Hausman test measures the correlation between the residuals of pooled least squares and the independent variables. The test suggested the use of fixedeffects specification for TEA, HEA rHEA models, although in some instances the test suggested the use of random-effects model. For consistency, we opted for using fixed-effects specification for all models. Fixed effects specification is less efficient than the random-effects specification due to loss in degrees of freedom, making it more conservative than the random-effects specification.

To eliminate collinearity problems, we removed any predictors with inter-correlations of 0.7 or greater. This resulted in the removal of the following controls from the model: government programmes; R\&D transfer; market openness ${ }^{15}$. The sigmamore specification was used when running the Hausman tests because the scales of the variables used were quite different from one another - a situation to which the Hausman test is occasionally sensitive. To control for potential heteroscedasticity in error terms arising from grouping by country, we specified robust standard errors when running the models ${ }^{16}$. There were only negligible differences between robust and non-robust specifications.

The final models tested the effect of the education EFC on Opportunity perception, Start-up skills, TEA, HEA, and rHEA with the controls described above, then tested the effect of EFCs on TEA, HEA, and rHEA with first Opportunity perception, and then Start-up skills added to the equation. In this way, we were able to test for possible mediation effects of Opportunity perception and Start-up skills on associations between the new business activity variables and education and training $E F C$ variables, as predicted by the GEM model. 


\section{$5 \quad$ Results}

Tables 1 and 2 indicate the results of the main tests of hypotheses $\mathrm{H} 1, \mathrm{H} 2$ and $\mathrm{H} 3$ for the full country sample and for high income countries only. Two-way significances are used for all variables in all tables. Fixed-effects GLS coefficients and significance levels are shown in the tables. In the interest of space, year effects are controlled but not shown.

Table 1 shows the results of the analysis for the two education EFCs, Opportunity perception, and types of entrepreneurial activity for all countries in our sample. The leftmost column shows effects on Opportunity perception, and the remaining columns show effects on the three entrepreneurial activity variables, with and without Opportunity perception present in the equation to test the mediation hypothesis H3. We find that, in the overall dataset, Opportunity perception is not significantly associated with either of the two education EFCs. We also find that all three entrepreneurial activity indices are positively and significantly associated with Opportunity perception. Also, all three entrepreneurial activity indices are positively and significantly associated with Higher education EFC. Thus, in the overall dataset, we find support for the expected direct effects of post-secondary entrepreneurship training and education and perception of opportunity (H1), as well as for opportunity perception and entrepreneurship indices (H2), but not for the mediation effect (H3). However, Higher education EFC exhibits positive, direct associations with indices of entrepreneurial activity.

There is good reason to believe that entrepreneurial activity might be associated with different national framework conditions in high- and low-income countries, respectively (Wennekers et al., 2005). We therefore ran the same analysis for the group of high-income countries, using the per-capita income of US\$20,000 as the threshold. This cut-off point gave us 27 countries and a total of 147 year-country observations to work with (average 5.4 observations per country). The results of this analysis are shown in Table 2.

As can be seen in Table 2, in the high income countries, Opportunity perception is significantly and positively associated with Higher Education EFC. Both TEA and HEA are also significantly and positively associated with Higher education EFC. However, when Opportunity perception is introduced in the equations, Higher education EFC loses its significance, and the effect of $O p$ - 
portunity perception emerges as significant. Thus, in the high-income countries, hypotheses $\mathrm{H} 1$, $\mathrm{H} 2$ and $\mathrm{H} 3$ receive support for TEA and HEA, but not for rHEA. Interestingly, for TEA, a negative and significant association is shown with Primary education EFC.

Tables 3 and 4 show the test of hypotheses H4, H5 and H6 concerning entrepreneurship training and education, perception of start-up skills and entrepreneurial activity. Again, we show separate analyses for the overall GEM dataset and for the subset of high-income countries.

The analysis comprising the full dataset is shown in Table 3. No statistically significant association is apparent for the relationship between Start-up skills and the two education EFCs. All entrepreneurial activity indices exhibit a positive and significant direct association with Higher education EFC. TEA and HEA, but not rHEA, exhibit a positive and significant association with Start-up skills. Thus, in the overall dataset, we have support for H4 (link between skills and measures of entrepreneurial activity) but not for H5 and H6 (effect of education on skills and the mediating effect). Again, we observe positive, direct associations between TEA and HEA and Higher education EFC.

The analysis comprising high-income countries is shown in Table 4. In this sub-set, there is a positive, statistically almost significant association between Higher education EFC and start-up skills. We also observe a mediation between Higher education EFC and start-up skills for TEA. However, similar mediation is not observed for HEA or $r H E A$, which do not exhibit any statistically significant association with start-up skills. Thus, for TEA, we have weak support for H5 (link between higher education and skills), support for H4 (link between skills and TEA), and support for H6 (the mediation effect). As for the overall sample, we also observe a direct link between Higher education EFC and HEA and rHEA.

\section{Discussion}

\subsection{Overview of findings}

We set out to provide the most rigorous test to date of the relationship between entrepreneurial education and training and GEM's measures of national entrepreneurial activity. Given the 
strong and continuing policy interest toward entrepreneurship education, we considered it important to examine whether it really impacts entrepreneurship, and whether the impact might differ for different types of entrepreneurial activity. After rigorously controlling for intervening influences, we found that entrepreneurship education probably does matter, and in quite specific ways. In high income countries, post-secondary entrepreneurship education and training is positively associated with the level of new business activity, including high-growth expectation business activity, by enhancing the level of opportunity perception in the population at large. On the other hand, the level of post-secondary entrepreneurship education and training appears to be only weakly associated with the level of skills, and it appears to affect only levels of new business activity, and not high-growth expectation entrepreneurial activity, through its effect on perceived start-up skills.

The finding that entrepreneurship training affects new business activity primarily through enhancing opportunity perception, rather than start-up skills perception, has several implications for policy. The received literature on entrepreneurship education has tended to emphasise the role of education in the provision of instrumental skills to start up new firms. However, even though the perception of skills is directly associated with the level of new business activity in a country, education appears to have little role in fostering such skills. There are several possible explanations for this. One reason for this finding may be that education, post-secondary education in particular, tends to focus more on theory than practice. Thus, the observed lack of mediation may simply signal that entrepreneurship training and education is not practice-oriented enough to cultivate instrumental start-up skills within the population. An alternative explanation may be that the skill-set required to start new firms is too general and broad-based to be effectively taught in educational institutions, and they may be better acquired through work experience. A third possible reason may be that the necessary skill set may incorporate intangible social resources, such as entrepreneur-centric social capital, which are likely acquired through experience rather than through formal education and training. Finally, it may be that entrepreneurship education and training may not have advanced to the level of, say, medical schools in equipping students with the skills, knowledge and experience necessary to practice their profession. Whatever the reason, the findings suggest that the instrumental emphasis, that pervades 
much of received literature on entrepreneurship education and training, may be misplaced, at least in part.

The observed mediating effect between Higher education EFC, opportunity perception and entrepreneurial activity emphasises the cognitive aspects of entrepreneurship education and training. This finding is in line with the 'Austrian' perspective on entrepreneurship. Recognising and assessing opportunities for setting up new productive functions in the economy often involves complex cognitive processing. Where others may not 'see' anything, a cognitively endowed individual may see a significant business opportunity. It appears that, consistent with much of the 'Austrian' theorising, the cognitive aspect of the entrepreneurial market process may be the critical bottleneck for entrepreneurial activity, one which educational institutions may be well positioned to address ${ }^{17}$. Post-secondary entrepreneurship education may be performing an 'eyeopening' role - hence its effect on opportunity perception - but may not be sufficiently experiential to give trainees the confidence that they have the necessary experience.

The strongest signal emerging from this study is the importance of entrepreneurial education and training at levels that are appropriate to a country's level of development for both general and high-growth expectation entrepreneurial activity. During our analysis, we observed robust direct associations for Higher education EFC and types of entrepreneurial activity - high-potential entrepreneurial activity in high-income countries in particular. This pattern was robust to alternative model specifications and alternative specifications of control variables. Whether entrepreneurship education operates mainly through opportunity perception, skills or through some other unmeasured mechanism (e.g., social capital, personal networks and peer recognition), an important message for policy is that Higher education EFC appears to matter for high-income countries. Overall, the level of an individual's education is positively associated with his or her entrepreneurial growth aspirations (Autio and Acs, 2007) and entry into and success in selfemployment (Dolinsky et al.. 1993; Robinson and Sexton, 1994). Our findings suggest that providing entrepreneurship education and training at post-secondary-level educational institutions in high income countries will influence the career decisions of those individuals who are likely to possess the kind of skills, competencies and social capital required to launch high-growth ventures, at a crucial time of their personal and professional development. Even though most stu- 
dents will not, and probably should not, start new firms immediately after graduation, entrepreneurship training and education may have a long-lasting effect on their entrepreneurial alertness and motivation.

We offer four possible reasons why entrepreneurship education and training in post-secondary levels of education in high income countries operates to enhance both general new business activity and high-potential entrepreneurial activity. First, such training is targeted to a population cell that has, by virtue of its educational background and social standing, the best opportunities to start new high-growth ventures. Second, such training would reach high-potential individuals when they are at a crucial stage in their professional development and thus likely to be actively making career decisions. Third, such training helps improve both the entrepreneurial selfefficacy of high-potential individuals, as well as their perceptions of the social desirability of entrepreneurial career choices. Fourth, the alternatives of unproductive or destructive entrepreneurship are likely to be unattractive in high income countries, because rule of law is stronger. Thus, allocation of effort by highly educated individuals into productive entrepreneurship is likely to be relatively high in high income countries. All these factors serve to boost the entrepreneurial propensities of those most likely to have the skills, will and desire to succeed. Furthermore, the building of entrepreneurship education capability in colleges and universities will enable the provision of advanced training at continuing professional development level to graduates at any stage in their career. Such elite training of highly committed individuals is widely accepted in management but less so in entrepreneurship.

As regards the control variables, we found that few of the other EFCs influenced entrepreneurial activity. Even though bivariate correlations for EFCs and TEA can be observed for this variable in cross-sectional settings, those correlations disappear in a more rigorous test that controls for intervening influences. We infer from this that a given country's overall level of entrepreneurial activity (i.e., TEA) is not significantly affected by most external conditions that are directly addressable by national policy-makers. This would support Leibenstein's view that institutions, as distinct from opportunities, have little impact on entrepreneurship levels. 
Surprisingly, when controlling for year effects in the panel data, GDP per capita does not emerge as a significant influence on TEA in the present analysis, even though it does emerge as a negative and significant influence when not controlling for year effects. Of the various control variables, only the population prevalence of established entrepreneurs shows up as a statistically highly significant influence on opportunity perception, skills perception and entrepreneurial activity. An interesting mediation effect could also be observed for the prevalence rate of established entrepreneurs in the population, skills perception, and new business activity in rich countries (see Table 4). These results demonstrate the important role that the existing stock of business owner-managers plays in enhancing opportunity and skills perception, and not just as a direct source of entrepreneurial stock (Fischer and Reuber, 2003; Leibenstein, 1968). In high income countries, the size of the pool of experienced entrepreneurs appears to influence the level of high-growth expectation entrepreneurial activity through its influence on opportunity perception, and the level of general new business activity through its influence on skills perception.

Leibenstein recognised the value of links between entrepreneurs in building capacity as he sketched out his model of factors that affected entrepreneurial activity levels: "probably a significant part of such a model would be the interaction of different types of entrepreneurs to each other's activities" (1968: 80). This insight is supported by recent research on spinoff entrepreneurship (Klepper, 2002; Klepper and Sleeper 2005). While much of this interaction is not organised formally, there are excellent models of organised informal training for entrepreneurs by entrepreneurs, such as the Entrepreneurial Exchange in Scotland ${ }^{18}$. It is noteworthy that the Entrepreneurial Exchange was an initiative of a government agency that was rapidly taken over and funded by entrepreneurs themselves.

\subsection{Limitations}

When considering our findings, it should be kept in mind that our analysis is restricted to national-level data, and it is based on cross-sectional panel regressions. We are thus not following individuals over time. Even though the process proposed by the model appears to work at the population level, different patterns might be observed when using longitudinal individual-level 
data. We cannot exclude this possibility. Also, there are some cohort effects in our data. The principal effect, which applies to the 2001 cohort, may be a data issue that is in the process of being resolved. It may or may not make a difference to the findings.

Second, our EFC data is based on impressions of experts, rather than "hard" data. While it is true that for some EFCs, hard data is available for items that we chose to measure through experts' opinions, for example regulatory burdens (Djankov et al., 2002), in many cases hard data is missing or at best patchy. We see the GEM Expert Survey as complementary to research based on 'hard' data. Where our findings agree, such as where the effect of regulations on entry is concerned, (Klapper et al., 2006; Levie and Autio, 2008) this strengthens the credibility of both results and should provide more confidence to policy-makers.

Third, we did not operationalize motivation in our empirical analysis, despite its importance in the model itself (under the general heading of capacity) and in entrepreneurship research generally (Shane et al., 2003) and despite the role that entrepreneurship education and training is said to play in enhancing motivation to engage in new business activity (Peterman and Kennedy, 2003). There are several possible candidate measures of motivation in the GEM database, although none are ideal. Further work might explore this.

\subsection{Implications for Further Research}

A great deal remains to be done to test the GEM model. Leibenstein's theory suggests several hypotheses in relation to motivation and kinship wealth that were not tested in this analysis, but which could be. Harder measures of EFCs (such as in Botero et al., 2004 and Djankov et al., 2002) could be used to test the model in addition to the impressionistic opinions of experts. It has been argued that women face special barriers to entrepreneurship, such as legitimacy and access to funding (Murphy et al., 2007) and that training may be particularly important to female prospective entrepreneurs (Ghosh and Cheruvalath, 2007). Repeating the analysis for male and female entrepreneurship rates, separately, might show that different EFCs are important for males 
and females. Repeating the analysis for startups in different industries or technology levels could also reveal different effects.

\section{Notes}

1. The box labelled New Firms was originally labelled Business Dynamics (Reynolds et al., 1999), then from 2000 to 2003 was labelled Business Churning (Reynolds et al., 2000, 2001, 2002, 2003), and from 2004 to 2005 was labelled New Firms (Acs et al., 2005; Minniti et al., 2006). In the latest iteration (Bosma et al., 2008) it is labelled Early-stage Entrepreneurial Activity.

2. We would suggest adding the word "Economic" to this box in the GEM model.

3. For an alternative reconciliation of the Schumpeterian and Kirznerian positions, which the GEM model could also accommodate, see Leibenstein (1987).

4. Strictly speaking, Baumol's main focus was on the allocation of entrepreneurs into 'productive' and 'unproductive' activities. Baumol's notion of the allocation of effort can easily be extended to consider the allocation of effort into entrepreneurship in general.

5. In a 1978 update of his earlier paper, Leibenstein renamed this "innovational" entrepreneurship (Leibenstein, 1978: 40).

6. In relation to motivation, we note a recent review of entrepreneurial motivation by Shane et al. (2003) in which the authors urge researchers to control for opportunity in studies of motivation. The GEM model may act as a useful guide in this respect.

7. The focus of the GEM model is on what Baumol terms productive entrepreneurship. Thus it is not relevant to the GEM model whether, as Baumol suggests, some individuals are entrepreneurial and others are not, and the question is what makes entrepreneurs to choose productive over unproductive or destructive entrepreneurship, or whether anyone can behave entrepreneurially, as von Mises suggests, and the question is what prompts people to behave entrepreneurially rather than non-entrepreneurially.

8. Indeed, in some countries, entrepreneurs are not permitted to trade until they can prove they have acquired such facilities. See, for example http://www.doingbusiness.org/ExploreTopics/StartingBusiness/Details.aspx?economyid=195, accessed 21 June 2008 
9. The latter has been traditionally referred to by GEM as "Cultural and Social Norms". To distinguish it clearly from universal values, consideration might be given to changing the label to Entrepreneurial Attitudes.

10. We do not consider the effect of entrepreneurship education and training on motivation further in this paper.

11. The GEM 2000 - 2006 dataset covered the following high-income countries: Australia, Austria, Belgium, Canada, Czech Republic, Denmark, Finland, France, Germany, Greece, Hong Kong, Iceland, Ireland, Israel, Italy, Japan, Netherlands, New Zealand, Norway, Portugal, Singapore, Spain, Sweden, Switzerland, Taiwan, United Kingdom, USA. In addition, the dataset included the following low-income countries, defined as countries with GDP per capita less than US\$20,000: Argentina, Brazil, Chile, China, Colombia, Croatia, Ecuador, Hungary, India, Indonesia, Jamaica, Jordan, Latvia, Malaysia, Mexico, Peru, Philippines, Poland, Russia, Slovenia, South Africa, South Korea, Thailand, Turkey, Uganda, Uruguay, Venezuela.

12. Although Baumol sees his independent innovator as a synonym for Schumpeter's entrepreneur, we interpret Schumpeter's entrepreneur as the fulfiller of the function 'new business activity"; "not only those "independent" businessmen in an exchange economy who are usually so designated" (Schumpeter, 1934: 74).

13. In the data there were a number of unrealistically high job expectation figures. We carefully examined the shapes of job expectation distributions and determined that any start-up attempt expecting more than 996 jobs could be set to zero without biasing the distribution.

14. http://www.imf.org/external/ns/cs.aspx?id=28 - accessed in August 2007

15. Correlation matrix is available from the authors upon request.

16. We ran all tests using both fixed-effect and random-effect specification, as well as specifying robust and non-robust standard errors (i.e., with and without assuming heteroscedasticity in error terms). No major differences in results were observed, and none of the significant influences reported in this paper showed sensitivity to analysis specification. As a further check of robustness we also employed a large number of different variable combinations, as well as different model specifications. The core findings, as reported in Tables 1-4, were remarkably insensitive to model specifications.

17. An interesting pattern in the data, not reported here because of space and data limitations, concerned the differing role of primary and higher educational institutions in low- and high- 
A Theoretical Grounding and Test of the GEM model

income economies, respectively. Where we observed a mediating effect for higher education EFC, opportunity perception and entrepreneurship in high-income economies, a similar mediation was observed for primary education EFC, opportunity perception, and TEA in lowincome economies. This may suggest that the role of the educational system varies according to the level of economic development.

18. www.entrepreneurial-exchange.co.uk 
A Theoretical Grounding and Test of the GEM model

\section{References}

Acs, Z. \& Szerb, L. (2007). Entrepreneurship, economic growth and public policy. Small Business Economics, 28(2/3), 109-122

Acs, Z. \& Varga, A. (2005). Entrepreneurship, agglomeration and technological change. Small Business Economics, 24(3), 323-334

Acs, Z. (2006). How is entrepreneurship good for economic growth? Innovations 1, 97-107

Acs, Z. J. \& Audretsh, D. B. (1990). Innovation and small firms. (Boston: MIT Press)

Acs, Z. J., Arenius, P., Hay, M. \& Minniti, M. (2005). Global entrepreneurship monitor 2004 executive report. (Babson Park, MA and London, UK: Babson College and London Business School)

Acs, Z. J., Audretsch, D. B., Braunerhjelm, P., \& Carlsson, B. (2004). The missing link: The knowledge filter, entrepreneurship and endogenous growth. Discussion Paper, No.4783, December, Center for Economic Policy Research, London, UK

Acs, Z. J., Braunerhjelm, P., Audretsch, D. B., \& Carlsson, B. (2006). A knowledge spillover theory of entrepreneurship. CESIS WP 77. Washington, D.C: George Mason University

Acs, Z. J., Desai, S. \& Hessels, J. (2008). Entrepreneurship, economic development and institutions. Small Business Economics, this issue.

Acs, Z.J. \& Amorós, J.E. (2008). Entrepreneurship and competitiveness dynamics in Latin America. Small Business Economics, this issue.

Acs, Z.J., Desai, S. \& Klapper, L.F. (2008). What does "entrepreneurship" data really show? Small Business Economics, this issue.

Ajzen, I. (1991). The theory of planned behavior. Organizational Behavior and Human Decision Processes, 50(2), 179-211

Ardichvili, A. A., Cardozo, R. R., \& Ray, S. S. (2003). A theory of entrepreneurial opportunity identification and development. Journal of Business Venturing, 19(1), 105-123

Aronsson, M. (2004). Education matters - but does entrepreneurship education? An interview with David Birch. Academy of Management Learning and Education, 3(3), 289-292

Audretsch, D. B., Grilo, I. \& Thurik, A. R. (2007), Explaining entrepreneurship and the role of policy: a framework. In: Audretsch, D.B., Grilo, I., \& Thurik, A.R. (eds). The Handbook of Research on Entrepreneurship Policy. Edward Elgar, Cheltenham, UK: 1-17.

Audretsch, D. B., Grilo, I., \& Thurik, A. R. (Eds.) (2007). Handbook of entrepreneurship researchResearch on Entrepreneurship Policy.. (Cheltenham: Edward Elgar)

Audretsch, D., Keilbach, M. \& Lehman, E. (2006). Entrepreneurship and economic growth. (Oxford: Oxford University Press)

Autio, E. \& Acs, Z. (2007, June). Individual and country-level effects on growth aspiration in new ventures. (Paper presented at the Babson Entrepreneurship Research Conference, Madrid)

Autio, E. (2005). GEM 2005 report Report on highHigh-expectation Expectation entrepreneurshipEntrepreneurship. (London: Global Entrepreneurship Research AssociationGERA)

Autio, E. (2007). GEM 2007 report Report on highHigh-gGrowth entrepreneurshipEntrepreneurship. (London: Global Entrepreneurship Research AssociationGERA) 
A Theoretical Grounding and Test of the GEM model

Autio, E., Kronlund, M., \& Kovalainen, A. (2007). High-growth SME support initiatives in nine countries: Analysis, categorization, and recommendations. (In MoTa Industry (Ed.), Publications, 95. Helsinki: Ministry of Trade and Industry, Industries Department.)

Baltagi, B. H., \& Wu, P. X. (1999). Unequally spaced panel data regressions with AR(1) disturbances. Econometric Theory, 15, 814-823

Baumol, W. J. (1990). Entrepreneurship: Productive, unproductive, and destructive. Journal of Political Economy, 98(5), 893-921

Baumol, W. J. (2002). The free-market innovation machine. (Princeton: Princeton University Press)

Baumol, W. J. (2003). On Austrian analysis of entrepreneurship and my own. (In R. Koppl (Ed.), Austrian Economics and Entrepreneurial Studies, Vol. 6 (pp. 57-66). Amsterdam: Elsevier Science)

Béchard, J.-P. \& Grégoire, D. (2005). Entrepreneurship education research revisited: The case of higher education. Academy of Management Learning and Education, 4(1), 22-49

Bertrand, Y. (1995). Contemporary theories and practice in education. (Madison, WI: Atwood Publishing)

Bitzenis, A. \& Nito, E. (2005) Obstacles to entrepreneurship in a transition business environment: The case of Albania. Journal of Small Business and Enterprise Development, 12(4), 564-578

Bosma, N., Jones, K., Autio, E. \& Levie, J. (2008). Global entrepreneurship monitor 2007 executive report. (London: Global Entrepreneurship Research Association)

Botero, J., Djankov, S., La Porta, R., Lopez-de-Silanes, F., and Shleifer, A. (2004). The regulation of labor. Quarterly Journal of Economics, 119, 1339-1382

Boyd, N. G. \& Vozikis, G. S. (1994). The influence of self-efficacy on the development of entrepreneurial intentions and actions. Entrepreneurship Theory \& Practice, 18(4), 63-77

Brenner, R. (1992). Entrepreneurship and business ventures in the new commonwealth. Journal of Business Venturing, 7(6), 431-439

Business School and back. (New York: HarperBusiness)

Carree, M. A. \& Thurik, A. R. (2000). The life cycle of the U.S. tire industry. Southern Economic Journal, 67(2), 254-287

Carter, N. M., Gartner, W. B., \& Reynolds, P. D. (1996). Exploring start-up event sequences. Journal of Business Venturing, 11(3), 151-166

Cetorelli, N. \& Strahan, P. E. (2006). Finance as a barrier to entry: Bank competition and industry structure in local U.S. markets. The Journal of Finance, 61(1), 437-461

Chen, C. C., Greene, P. G., \& Crick, A. (1998). Does entrepreneurial self-efficacy distinguish entrepreneurs from managers? Journal of Business Venturing, 13, 295-316

Choo, S. \& Wong, M. (2006). Entrepreneurial intention: Triggers and barriers to new venture creations in Singapore. Singapore Management Review, 28(2), 47-64

Clarysse, B. \& Bruneel, J. (2007). Nurturing and growing innovative start-ups: The role of policy as integrator. $R \& D$ Management, 37(2), 139-149

Corbett, A. C. (2005). Experiential learning within the process of opportunity identification and exploitation. Entrepreneurship: Theory \& Practice, 29(4), 473-491

Cotis, J. P. (2007, January). Entrepreneurship as an engine for growth: Evidence and policy challenges. (Paper presented at GEM Forum: Entrepreneurship: Setting the development agenda, London) 
A Theoretical Grounding and Test of the GEM model

Dahles, H. (2005). Culture, capitalism and political entrepreneurship: Transnational business ventures of the Singapore Chinese in China. Culture \& Organization, 11(1), 45-58

Davidsson, P. \& Henrekson, M. (2002). Determinants of the prevalence of start-ups and high-growth firms. Small Business Economics, 19(2), 81-104

Delmar, F. \& Shane, S. (2003). Does business planning facilitate the development of new ventures? Strategic Management Journal, 24(12), 1165-1185

DeTienne, D. \& Chandler, G. (2004). Opportunity identification and its role in the entrepreneurial classroom: A pedagogical approach and empirical test. Academy of Management Learning and Education, 3(3), 242-257

Directorate-General Enterprise (2004). Benchmarking enterprise policy: Results from the 2004 scoreboard. Commission Staff Working Document SEC (2004) 1427, November

Djankov, S., La Porta, R., Lopez-de-Silanes, F., \& Shleifer, A. (2002). The regulation of entry. Quarterly Journal of Economics, 117, 1-35

Dolinsky, A. L., Caputo, R. K., Pasumarty, K., \& Quazi, H. (1993). The effects of education on business ownership: A longitudinal study of women. Entrepreneurship Theory \& Practice, 18(1), 43-53

Dreher, A. \& Gassebner, M. (2007). Greasing the wheels of entrepreneurship? Impact of regulations and corruption on firm entry. KOF WP 166. Zurich: KOF Swiss Economic Institute.

Dubini, P. (1989). The influence of motivations and environment on business start-ups: Some hints for public policies. Journal of Business Venturing, 4(1), 11-26

Eckhardt, J. T. \& Shane, S. A. (2003). Opportunities and entrepreneurship. Journal of Management, 29(3), 333-349

Etzioni, A. (1987). Entrepreneurship, adaptation and legitimation. Journal of Economic Behavior, 8, 175189

Fayolle, A. (2000). Exploratory study to assess the effects of entrepreneurship programs on French student entrepreneurial behaviors. Journal of Enterprising Culture, 8(2), 169-184

Fiet, J. O. (2000). The theoretical side of teaching entrepreneurship. Journal of Business Venturing, 16, 124

Finnerty, J. \& Krzystofik, A. T. (1985). Barriers to small business formation. Journal of Small Business Management, 23(3), 50-58

Fischer, E. \& Reuber, A. R. (2003). Support for rapid-growth firms: A comparison of the views of founders, government policymakers, and private sector resource providers. Journal of Small Business Management, 41(4), 346-365

Fisman, R. \& Sarria-Allende, V. (2004). Regulation of entry and the distortion of industrial organization. WP 10929, National Bureau of Economic Research

Garavan, T. N. \& O'Cinneide, B. (1994). Entrepreneurship education and training programmes: A review and evaluation part 1. Journal of European Industrial Training, 18(8), 3-12

Gartner, W., Bird, B., \& Starr, J. (1992). Acting as if: Differentiating entrepreneurial from organizational behaviour. Entrepreneurship Theory \& Practice, 16(3), 13-32

George, G. G. \& Zahra, S. A. S. 2002. Culture and Its consequences for entrepreneurship. Entrepreneurship Theory \& Practice, 26(4), 5-8

Geroski, P. A. (1989). Entry, Innovation and Productivity Growth. The Review of Economics and Statistics, 71(4), 572-578 
A Theoretical Grounding and Test of the GEM model

Geroski, P. A. (1995). What do we know about entry? International Journal of Industrial Organization, $13,421-440$

Ghosh, P. \& Cheruvalath, R. (2007). Indian female entrepreneurs as catalysts for economic growth and development. International Journal of Entrepreneurship and Innovation, 8(2), 139-148

Goldfarb, B. \& Henrekson, M. (2003). Bottom-up versus top-down policies towards the commercialization of university intellectual property. Research Policy, 32(4), 639-658

Grilo, I., \& Irigoyen, J. M. (2006). Entrepreneurship in the EU: To wish and not to be. Small Business Economics, 26(4): 305-318.

Hansen, J. \& Sebora, T.C. (2003). Applying principles of corporate entrepreneurship to achieve national economic growth. Advances in the Study of Entrepreneurship, Innovation, and Economic Growth, $14,69-90$

Hawkins, D. I. (1993). New business entrepreneurship in the Japanese economy. Journal of Business Venturing, 8(2), 137-150

Hayek, F. A. v. (1945). The use of knowledge in society. American Economic Review, 35(4), 519-530

Hayek, F. A. v. (1978). Competition as a discovery procedure. (In F. A. v. Hayek (Ed.), New studies in philosophy, politics, economics, and the history of ideas (pp.179-190). Chicago: University of Chicago Press.)

Hayton J. C. J., George G. G., \& Zahra S. A. S. (2002). National culture and entrepreneurship: A review of behavioral research. Entrepreneurship Theory \& Practice, 26(4), 33-52

Heinonen, J. \& Poikkijoki, S.-A. (2006). An entrepreneurial-directed approach to entrepreneurship education: Mission impossible? Journal of Management Development, 25(1), 80-94

Helms, M. H. (2003). The challenge of entrepreneurship in a developed economy: The problematic case of Japan. Journal of Developmental Entrepreneurship, 8(3), 247-264

Hofstede G. (1980). Culture's consequences: International differences in work-related values. (Beverly Hills, CA: Sage Publishers)

Hofstede, G., Noorderhaven, N.G., Thurik, A.R., Wennekers, A.R.M., Uhlaner, L., \& Wildeman, R.E. (2003). Culture's role in entrepreneurship: self-employment out of dissatisfaction. In: Uljin, J., \& Brown, T. (eds). Innovation, Entrepreneurship and Culture: The Interaction between Technology, Progress and Economic Growth. Edward Elgar: Cheltenham, UK: 162-203.

Honig, B. (2004). Entrepreneurship education: Toward a model of contingency-based business planning. Academy of Management Learning and Education, 3(3), 258-273

House, R. J. (1998). A brief history of GLOBE. Journal of Managerial Psychology, 13(3/4), 230-240

Hunt, S. \& Levie, J. (2004). Culture as a predictor of entrepreneurial activity. (In W. D. Bygrave, C. G. Brush, P. Davidsson, J. O. Fiet, P. G. Greene, R. T. Harrison, M. Lerner, G. D. Meyer, J. Sohl, \& A. Zacharakis (Eds.), Frontiers of Entrepreneurship Research 2003 (pp. 171-185). Babson Park, MA: Babson College.)

Inglehart, R. (1997). Modernization and post modernization: Culture, economic and political change in 43 societies. (Princeton: Princeton University Press)

Javidan, M., House, R. J., Dorfman,, P. W., Hanges, P. J. \& Sully de Luque, M. (2006). Conceptualizing and measuring cultures and their consequences: a comparative review of GLOBE's and Hofstede's approaches. Journal of International Business Studies, 37, 897-914 
A Theoretical Grounding and Test of the GEM model

Kaufmann, P. J., Welsh, D. H. B., \& Bushmarin, B. V. (1995). Locus of control and entrepreneurship in the Russian Republic. Entrepreneurship Theory \& Practice, 20(1), 43-57

Kawai, H. \& Urata, S. (2002). Entry of small and medium enterprises and economic dynamism in Japan. Small Business Economics, 18, 41-52

Keuschnigg, C. \& Nielsen, S. B. (2001). Public policy for venture capital. International Tax and Public Finance, 8(4), 557-572

Keuschnigg, C. \& Nielsen, S. B. (2002). Tax policy, venture capital, and entrepreneurship. Journal of Public Economics, 87(1), 175-203

Keuschnigg, C. \& Nielsen, S. B. (2004). Start-ups, venture capitalists, and the capital gains tax. Journal of Public Economics, 88(5), 1011-1042

Kirchhoff, B. (1994). Entrepreneurship and dynamic capitalism. (Westport, CT: Praeger)

Kirzner, I. (1973). Competition and entrepreneurship. (Chicago, IL: University of Chicago Press)

Kirzner, I. (1979). Perception, opportunity and profit. (Chicago, IL: University of Chicago Press)

Kirzner, I. (1985). The perils of regulation: A market process approach. (In I. Kirzner, (Ed.) Discovery and the capitalist process. (pp.119-149). Chicago, IL: University of Chicago Press.)

Kirzner, I. (1997a). How markets work: Disequilibrium, entrepreneurship and discovery. IEA Hobart Paper 133. London: Institute of Economic Affairs

Kirzner, I. (1997b). Entrepreneurial discovery and the competitive market process: An Austrian approach. Journal of Economic Literature, 35, 60-85

Klapper, L., Laeven, L., \& Rajan, R. (2006). Entry regulation as a barrier to entrepreneurship. Journal of Financial Economics, 82, 591-629

Klepper, S. \& Sleeper, S. (2005). Entry by spinoffs. Management Science, 51(8), 1291-1306

Klepper, S. (1996). Entry, exit, growth, and innovation over the product life cycle. American Economic Review, 86, 562-583

Klepper, S. (2002). The capabilities of new firms and the evolution of the US automobile industry. Industrial and Corporate Change, 11(4), 645-666

Kögel, T. (2004). Did the association between fertility and female employment within OECD countries really change its sign? Journal of Population Economics, 17, 45-65

Kouriloff, M. (2000). Exploring perceptions of a priori barriers to entrepreneurship: A multidisciplinary approach. Entrepreneurship Theory \& Practice, 25(2), 59-79

Lazear, E. (2004). Balanced skills and entrepreneurship. American Economic Review, 94(2), 208-211

Lazear, E. P. (2005). Entrepreneurship. Journal of Labor Economics, 23(4), 649-680

Leibenstein, H. (1966). Allocative efficiency vs. X-Efficiency. American Economic Review, 56(3), 392415

Leibenstein, H. (1968). Entrepreneurship and development. The American Economic Review, 58(2), 7283

Leibenstein, H. (1978). General X-efficiency theory and economic development. (Oxford, UK: Oxford University Press)

Leibenstein, H. (1987). Entrepreneurship, entrepreneurial training and X-efficiency. Journal of Economic Bahavior and Organization, 8, 191-205 
A Theoretical Grounding and Test of the GEM model

Leibenstein, H. (1995). The supply of entrepreneurship. (In G. M. Meier (Ed.), Leading issues in economic development (pp. 273-275). New York: Oxford University Press.)

Levie, J. \& Autio, E. (2008). Regulation of entry, rule of law, and entrepreneurship: an international panel study. Hunter Centre for Entrepreneurship working paper. Glasgow, UK: University of Strathclyde.

Levie, J. \& Hunt, S. (2005) Culture, institutions and new business activity: Evidence from global entrepreneurship monitor. (In S. A. Zahra, C. G. Brush, P. Davidsson, J. Fiet, P. G. Greene, R. T. Harrison, M. Lerner, C. Mason, G. D. Meyer, J. Sohl, \& A. Zacharakis (Eds.), Frontiers of entrepreneurship research 2004 (pp. 519-533). Babson Park, MA: Babson College.)

Levie, J. (2006). From business plans to business shaping: Reflections on an experiential new venture creation class. WP 040/2006. London, UK: National Council for Graduate Entrepreneurship

Liao, J., Welsch, H. P., \& Pistrui, D. (2001). Environmental and individual determinants of entrepreneurial growth: An empirical examination. Journal of Enterprising Culture, 9(3), 253-272

Lopez-Claros, A., Porter, M.E., Schwab, K. \& Sala-i-Martin, X. (2006). The global competitiveness report 2006-2007. (London, UK: Palgrave-Macmillan)

Lundström, A. \& Stevenson, L. (2005). Entrepreneurship policy: Theory \& practice. (New York: Springer-Verlag)

Maddy, M. (2000). Dream deferred: The story of a high-tech entrepreneur in a low-tech world. Harvard Business Review, 78(3), 57-69

Maddy, M. (2004). Learning to love Africa: My journey from Africa to Harvard

Malerba, F. \& Orsenigo, L. (1996). Schumpeterian patterns of innovation are technology-specific. Research Policy, 25, 451-478

Michelacci, C. (2003). Low returns in R\&D due to the lack of entrepreneurial skills. The Economic Journal, 113(484), 207-225

Minniti M., with Bygrave W. D., \& Autio E. (2006). Global entrepreneurship monitor 2005 executive report. (Babson Park, MA and London, UK: Babson College and London Business School)

Murphy, K. M, Schleifer, A. \& Vishny, R. W. (1991). The allocation of talent: Implications for growth. The Quarterly Journal of Economics, 106(2), 503-530

Murphy, P. J., Kickul, J., Barbosa, S. D. \& Titus, L. (2007). Expert capital and perceived legitimacy: Female-run entrepreneurial venture signalling and performance. International Journal of Entrepreneurship and Innovation, 8(2), 127-138

Parker, S. C. (2006). Entrepreneurship, self-employment, and the labour market. (In M. Casson,, B. Yeung, A. Basu \& N. Wadeson (Eds.), Oxford handbook of entrepreneurship (pp.435-460). Oxford: Oxford University Press.)

Peterman, N. \& Kennedy, J. (2003). Enterprise education: Influencing students' perceptions of entrepreneurship. Entrepreneurship Theory \& Practice, 28, 129-144

Puffer, S. M. \& McCarthy, D. J. (2001). Navigating the hostile maze: A framework for Russian entrepreneurship. Academy of Management Executive, 15(4), 24-36

Reynolds P. D., Bosma N., Autio, E., De Bono, N, Servais, I., Lopez-Garcia, P., \& Chin, N. (2005). Global entrepreneurship monitor: Data collection design and implementation 1998-2003. Small Business Economics, 24(3), 205-231

Reynolds, P. D., Bygrave, W. D., Autio, E., \& others (2003). Global entrepreneurship monitor 2003 executive report. (Babson Park, MA and London, UK: Babson College and London Business School) 
A Theoretical Grounding and Test of the GEM model

Reynolds, P. D., Bygrave, W. D., Autio, E., Cox, L. W. \& Hay, M. (2002). Global entrepreneurship monitor 2002 executive report. (Babson Park, MA and London, UK: Babson College and London Business School)

Reynolds, P. D., Camp, S. M., Bygrave, W. D., Autio, E. \& Hay, M. (2001). Global entrepreneurship monitor 2001 executive report. (Babson Park, MA and London, UK: Babson College and London Business School)

Reynolds, P. D., Hay, M., Bygrave, W. D., Camp, S. M., \& Autio, E. (2000). Global entrepreneurship monitor 2000 executive report. (Babson Park, MA and London, UK: Babson College and London Business School)

Reynolds, P. D., Rauch, A., Lopez-Garcia, P., \& Autio, E. (2001, February). Data collection-analysis strategies operations manual. Internal GEM Document. London: London Business School

Reynolds, P.D. (2008). Personal email communication, 5 June 2008.

Robertson, A., Collins, A., Medeira, N \& Slater, J. (2003). Barriers to start-up and their effect on aspirant entrepreneurs. Education \& Training, 45(6), 308-316

Robinson, P. B. \& Sexton, E. A. (1994). The effect of education and experience on self-employment success. Journal of Business Venturing, 9(2), 141-156

Romer, P. M. 1990. Endogenous technological change. The Journal of Political Economy, 98(5), 71-102

Rosa, P. \& Scott, M. (1999). Entrepreneurial diversification, business-cluster formation, and growth. Environment and Planning C: Government and Policy, 17(5), 527-547

Ruef, M. (2005). Origins of organizations: The entrepreneurial process. (Review). Research in the Sociology of Work, 15, 63-100

Schumpeter J. A. (1934) The theory of economic development. (Cambridge, MA: Harvard University Press)

Schumpeter, J. A. (1947a). Capitalism, socialism and democracy. $2^{\text {nd }}$ edition. (London: George Allen \& Unwin)

Schumpeter, J. A. (1947b). The creative response in economic history. Journal of Economic History, 7, $149-159$

Schwartz, S. (1994). Beyond individualism/collectivism: New cultural dimensions of values. (In U. Kim, H. C. Triandis, C. Kagitcibasi, S-C. Choi, \& G. Yoon (Eds.), Individualism and collectivism: Theory, methods and applications (pp.85-119). London: Sage.)

Shane, S. \& Venkataraman, S. (2000). The promise of entrepreneurship as a field of research. Academy of Management Review, 25, 217-226

Shane, S. (2002). Executive Forum: University technology transfer to entrepreneurial companies. Journal of Business Venturing, 17(6), 537-552

Shane, S. (2003). A general theory of entrepreneurship: The individual-opportunity nexus. (Cheltenham: Edward Elgar.)

Shane, S. 2000. Prior knowledge and the discovery of entrepreneurial opportunities. Organization Science, 11(4), 448-469

Shane, S., Locke, E. \& Collins, C. J. (2003). Entrepreneurial motivation. Human Resource Management Review, 13, 257-279 
A Theoretical Grounding and Test of the GEM model

Shrader, R. \& Siegel, D. S. (2007). Assessing the relationship between human capital and firm performance: Evidence from technology-based new ventures. Entrepreneurship Theory \& Practice, 31(6), 893-908

Smith: B., Peterson, M. F. \& Schwartz, S. H. (2002). Cultural values, sources of guidance, and their relevance to managerial behavior. Journal of Cross-Cultural Psychology, 33(2), 188-208

Spencer, J. W. \& Gomez, C. (2004). The relationship among national institutional structures, economic factors, and domestic entrepreneurial activity: A multicountry study. Journal of Business Research, 57, 1098-1107

Storey, D. J. \& Tether, B. S. (1998). Public policy measures to support new technology-based firms in the European Union. Research Policy, 26(9), 1037-1057

Storey, D. J. (1994). Understanding the small business sector. (London, UK: Routledge)

Suzuki, K., Kim, S. H., \& Bae, Z. T. (2002). Entrepreneurship in Japan and Silicon Valley: a comparative study. Technovation, 22(10), 595-606

Trulsson, P. (2002). Constraints of growth-oriented enterprises in the southern and eastern African region. Journal of Developmental Entrepreneurship, 7(3), 331-339

Uhlaner, Uhlaner, L.M. and A.R. Thurik (2007), Post-materialism: a cultural factor influencing total entrepreneurial activity across nations, Journal of Evolutionary Economics, 17(2), 161-185.

Van der Horst, R., Nijsen, A. \& Gulhan, S. (2000). Regulatory policies and their impact on SMEs in Europe: The case of administrative burdens. (In D. Sexton \& H. Landstrom (Eds.), Blackwell handbook of entrepreneurship (pp.128-149). Malden, MA: Blackwell Publishing.)

van Stel A., Carree M., \& Thurik R. (2005). The effect of entrepreneurial activity on national economic growth. Small Business Economics, 24(3), 311-321

van Stel, A., Storey, D., \& Thurik, A. R. (2007). The effect of business regulations on nascent to young business entrepreneurship. Small Business Economics, 28(2/3), 171-186.

Volery, T., Doss, T, Mazzarol, T. \& Thein, V. (1997, June). Triggers and barriers affecting entrepreneurial intentionality: The case of western Australian nascent entrepreneurs. (Paper presented at $42^{\text {nd }}$ ICSB World Conference, San Francisco)

Von Mises, L. (1949). Human action. (New Haven: Yale University Press)

Wennekers S., van Wennekers, R., Thurik R. \& Reynolds P. (2005). Nascent entrepreneurship and the level of economic development. Small Business Economics, 24(3), 293-309

Witt, U. (2002). How evolutionary is Schumpeter's theory of economic development? Industry and Innovation, 9(1/2), 7-22

Wright, M., Hmieleski, K. M., Siegel, D. S., \& Ensley, M. D. (2007). The role of human capital in technological entrepreneurship. Entrepreneurship Theory \& Practice, 31(6), 791-806 
Entrepreneurial Framework Conditions and Entrepreneurial Activity

Figure 1 GEM conceptual Model (Taken from Acs et al., 2005: 14)

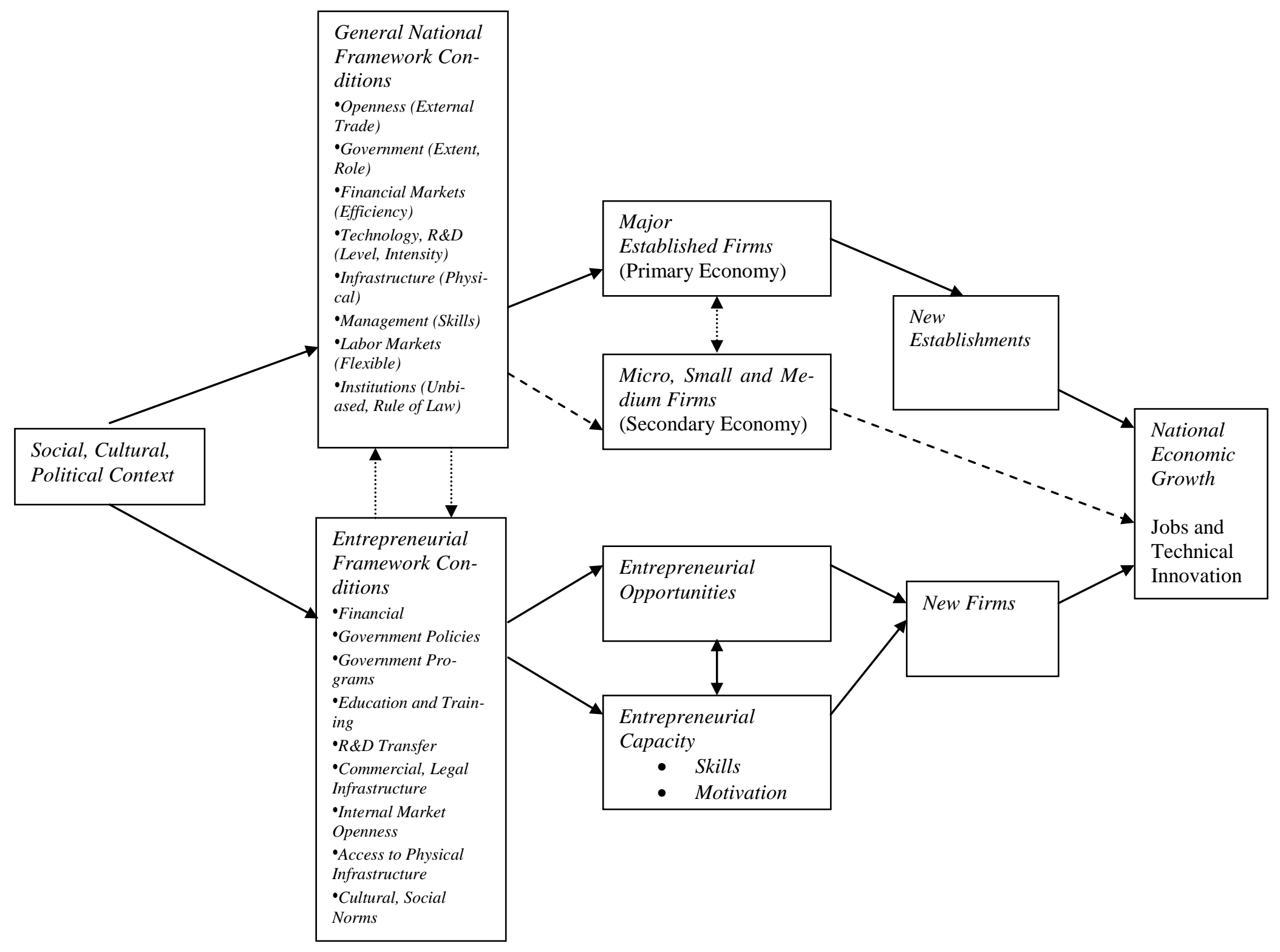


Entrepreneurial Framework Conditions and Entrepreneurial Activity

Table 1 Opportunity perception, entrepreneurship education and training, and entrepreneurial activity in the overall GEM 2000 - 2006 dataset

\begin{tabular}{|c|c|c|c|c|c|c|c|}
\hline \multicolumn{8}{|c|}{ Overall Dataset } \\
\hline & Opportunity & TEA & TEA & HEA & HEA & rHEA & rHEA \\
\hline GDP per cap (ppp) & $-2,41 \mathrm{E}-05$ & $1,57 \mathrm{E}-06$ & $5,11 \mathrm{E}-06$ & $-1,33 \mathrm{E}-07$ & $1,80 \mathrm{E}-07$ & $-2,29 \mathrm{E}-06$ & $-1,11 \mathrm{E}-06$ \\
\hline GDP per cap (squared) & 4,11E-10 & $4,63 \mathrm{E}-11$ & $-1,30 \mathrm{E}-11$ & 2,14E-12 & $-3,82 \mathrm{E}-12$ & $3,46 \mathrm{E}-11$ & 1,19E-11 \\
\hline GDP change & $0,0037+$ & 0,0014 & 0,0009 & 0,0002 & 0,0002 & 0,0019 * & $0,0018+$ \\
\hline Population Growth & 0,9196 & $-0,3995$ & $-0,5298$ & $-0,0806$ & $-0,0847$ & $-0,4096$ & $-0,3839$ \\
\hline Estab. e-ship rate & 0,5939 * & 0,1723 * & $0,1287+$ & 0,0120 & 0,0046 & 0,0146 & $-0,0485$ \\
\hline Finance EFC & $-0,0508$ * & $-0,0030$ & 0,0024 & 0,0003 & 0,0009 & 0,0040 & 0,0072 \\
\hline Policy EFC & 0,0471 & $-0,0016$ & $-0,0057$ & 0,0005 & 0,0002 & 0,0007 & 0,0001 \\
\hline Regulations EFC & $-0,0099$ & 0,0024 & 0,0028 & 0,0002 & $-0,0004$ & 0,0134 & 0,0074 \\
\hline Business services EFC & 0,0074 & $-0,0101$ & $-0,0056$ & $-0,0026$ & $-0,0020$ & $-0,0330+$ & $-0,0322+$ \\
\hline Market dynamism EFC & 0,0460 * & $-0,0041$ & $-0,0130+$ & $-0,0007$ & $-0,0018$ & $-0,0034$ & $-0,0099$ \\
\hline Physical infra EFC & $-0,0210$ & 0,0016 & 0,0033 & $-0,0003$ & 0,0002 & $-0,0066$ & $-0,0013$ \\
\hline Entrep culture EFC & 0,0006 & 0,0012 & 0,0034 & $-0,0007$ & $-0,0008$ & $-0,0088$ & $-0,0145$ \\
\hline Opportunity perception & & & $0,1320^{* \star \star}$ & & $0,0165^{* \star *}$ & & $0,1025^{*}$ \\
\hline Primary education EFC & 0,0219 & $-0,0036$ & $-0,0060$ & $-0,0009$ & $-0,0015$ & $-0,0048$ & $-0,0099$ \\
\hline Higher education EFC & 0,0286 & $0,0138+$ & 0,0129 & 0,0049 * & 0,0054 ** & 0,0366 * & 0,0395 ** \\
\hline R-sq (within) & 0,3604 & 0,1916 & 0,3416 & 0,1437 & 0,2594 & 0,1259 & 0,1779 \\
\hline Observations & 212 & 224 & 212 & 224 & 212 & 224 & 212 \\
\hline Groups & 47 & 48 & 47 & 48 & 47 & 48 & 47 \\
\hline Prob $>F$ & $0,000 * * *$ & $0,000 * * *$ & $0,000 * * *$ & $0,000 * * *$ & $0,000 * * *$ & $0,000 * * *$ & $0,000^{* * *}$ \\
\hline
\end{tabular}

Note: GLS coefficients; 2 -tailed significances; $p<0,001^{* * * ;} ;<0,01^{* *}: \mathrm{p}<0,05^{*} ; \mathrm{p}<0,1+$

Note: Year effects controlled but not shown.

Table 2 Opportunity perception, entrepreneurship education and training, and entrepreneurial activity in high-income countries (GEM 2000 - 2006 dataset)

\begin{tabular}{|c|c|c|c|c|c|c|c|}
\hline \multicolumn{8}{|c|}{ High-Income Countries (GDP per capita over 20 kUSD) } \\
\hline & Opportunity & TEA & TEA & HEA & HEA & rHEA & rHEA \\
\hline GDP per cap (ppp) & $-5,91 E-06$ & $7,45 \mathrm{E}-06$ * & $8,10 \mathrm{E}-06$ ** & $9,54 \mathrm{E}-07$ & $1,06 \mathrm{E}-06$ * & $-1,82 \mathrm{E}-06$ & $-1,01 \mathrm{E}-06$ \\
\hline GDP per cap (squared) & $1,38 \mathrm{E}-10$ & $-1,22 \mathrm{E}-10 *$ & $-1,36 \mathrm{E}-10$ * & $-1,85 \mathrm{E}-11$ & $-2,09 \mathrm{E}-11+$ & $1,04 \mathrm{E}-10$ & $8,26 \mathrm{E}-11$ \\
\hline GDP change & $-0,0022$ & $-0,0013$ & $-0,0011$ & $-0,0002$ & $-0,0002$ & 0,0009 & 0,0011 \\
\hline Population Growth & $-1,0611$ & $-0,2332$ & $-0,1757$ & $-0,0541$ & $-0,0184$ & $-0,3103$ & 0,0226 \\
\hline Estab. e-ship rate & 0,5666 ** & 0,1638 ** & 0,1278 ** & $0,0207+$ & 0,0079 & 0,0138 & $-0,0991$ \\
\hline Finance EFC & $-0,0448$ * & 0,0032 & 0,0054 & 0,0012 & 0,0024 * & 0,0136 & $0,0238+$ \\
\hline Policy EFC & 0,0299 & $-0,0028$ & $-0,0040$ & 0,0002 & $-0,0003$ & 0,0049 & 0,0004 \\
\hline Regulations EFC & $-0,0291$ & $0,0091+$ & 0,0083 & 0,0012 & 0,0012 & 0,0167 & 0,0180 \\
\hline Business services EFC & $-0,0129$ & $-0,0185^{*}$ & $-0,0143$ & $-0,0052 * *$ & $-0,0043$ * & $-0,0535 *$ & $-0,0462+$ \\
\hline Market dynamism EFC & 0,0087 & $-0,0056$ & $-0,0093$ & $-0,0005$ & $-0,0010$ & 0,0013 & $-0,0027$ \\
\hline Physical infra EFC & $-0,0222$ & $-0,0054$ & $-0,0047$ & $-0,0012$ & $-0,0004$ & $-0,0146$ & $-0,0068$ \\
\hline Entrep culture EFC & 0,0100 & 0,0007 & 0,0011 & $-0,0015$ & $-0,0022$ * & $-0,0207$ & $-0,0279$ \\
\hline Opportunity perception & & & $0,0677^{*}$ & & 0,0219 ** & & $0,1961^{*}$ \\
\hline Primary education EFC & $-0,0619$ & $-0,0144$ * & $-0,0103$ & $-0,0020$ & $-0,0012$ & 0,0037 & 0,0115 \\
\hline Higher education EFC & 0,0792 ** & 0,0151 * & 0,0092 & 0,0039 * & 0,0032 & 0,0253 & 0,0197 \\
\hline R-sq (within) & 0,4972 & 0,3881 & 0,4293 & 0,2575 & 0,3898 & 0,1804 & 0,2470 \\
\hline Observations & 143 & 147 & 143 & 147 & 143 & 147 & 143 \\
\hline Groups & 27 & 27 & 27 & 27 & 27 & 27 & 27 \\
\hline Prob $>\mathrm{F}$ & $0,000^{* * *}$ & $0,000 * * *$ & $0,000 * * *$ & $0,000 * * *$ & $0,000 * * *$ & $0,000^{* * *}$ & $0,000 * * *$ \\
\hline
\end{tabular}

Note: GLS coefficients; 2-tailed significances; $p<0,001^{* * * ;}$ < $<0,01^{* *}$ : $p<0,05^{*} ; \mathrm{p}<0,1+$

Note: Year effects controlled but not shown. 
A Theoretical Grounding and Test of the GEM model

Table 3 Perception of start-up skills, entrepreneurship education and training, and entrepreneurial activity in the overall GEM 2000 - 2006 dataset

\begin{tabular}{|c|c|c|c|c|c|c|c|}
\hline \multicolumn{8}{|c|}{ Overall Dataset } \\
\hline & Skill & TEA & TEA & HEA & HEA & rHEA & rHEA \\
\hline GDP per cap (ppp) & 4,54E-06 & 1,57E-06 & $-3,10 \mathrm{E}-07$ & $-1,33 \mathrm{E}-07$ & $-6,91 \mathrm{E}-07$ & $-2,29 \mathrm{E}-06$ & $-6,50 \mathrm{E}-06$ \\
\hline GDP per cap (squared) & $-1,00 \mathrm{E}-10$ & $4,63 \mathrm{E}-11$ & $6,75 \mathrm{E}-11$ & $2,14 \mathrm{E}-12$ & $7,81 \mathrm{E}-12$ & $3,46 \mathrm{E}-11$ & $5,52 \mathrm{E}-11$ \\
\hline GDP change & 0,0167 ** & 0,0014 & 0,0002 & 0,0002 & 0,0002 & 0,0019 * & 0,0029 * \\
\hline Population Growth & $-1,3642$ & $-0,3995$ & $-0,0103$ & $-0,0806$ & $-0,0657$ & $-0,4096$ & 0,1891 \\
\hline Estab. e-ship rate & 0,2889 & 0,1723 * & 0,1296 * & 0,0120 & 0,0069 & 0,0146 & 0,0222 \\
\hline Finance EFC & 0,0022 & $-0,0030$ & $-0,0093$ & 0,0003 & $-0,0010$ & 0,0040 & $-0,0114$ \\
\hline Policy EFC & $-0,0045$ & $-0,0016$ & 0,0086 & 0,0005 & 0,0019 & 0,0007 & 0,0009 \\
\hline Regulations EFC & $-0,0008$ & 0,0024 & $-0,0020$ & 0,0002 & $-0,0008$ & 0,0134 & 0,0233 \\
\hline Business services EFC & $-0,0572$ & $-0,0101$ & 0,0000 & $-0,0026$ & $-0,0007$ & $-0,0330+$ & $-0,0286$ \\
\hline Market dynamism EFC & 0,0146 & $-0,0041$ & $-0,0138$ & $-0,0007$ & $-0,0019$ & $-0,0034$ & $-0,0090$ \\
\hline Physical infra EFC & 0,0517 & 0,0016 & $-0,0043$ & $-0,0003$ & 0,0000 & $-0,0066$ & $-0,0088$ \\
\hline Entrep culture EFC & 0,0077 & 0,0012 & 0,0057 & $-0,0007$ & 0,0004 & $-0,0088$ & $-0,0063$ \\
\hline Start-up skills & & & 0,0730 * & & $0,0056+$ & & 0,0128 \\
\hline Primary education EFC & $-0,0107$ & $-0,0036$ & $-0,0058$ & $-0,0009$ & $-0,0018$ & $-0,0048$ & $-0,0151$ \\
\hline Higher education EFC & 0,0208 & $0,0138+$ & 0,0161 * & 0,0049 * & 0,0056 ** & 0,0366 * & 0,0496 ** \\
\hline R-sq (within) & 0,4035 & 0,1916 & 0,2906 & 0,1437 & 0,2534 & 0,1259 & 0,1930 \\
\hline Observations & 194 & 224 & 194 & 224 & 194 & 224 & 194 \\
\hline Groups & 47 & 48 & 47 & 48 & 47 & 48 & 47 \\
\hline Prob $>F$ & $0,000 * * *$ & $0,000 * * *$ & $0,000 * * *$ & $0,000 * * *$ & $0,000 * * *$ & $0,000 * * *$ & $0,000 * * *$ \\
\hline
\end{tabular}

Note: GLS coefficients; 2-tailed significances; $p<0,001^{* * *} ; p<0,01 * *$ : $p<0,05^{*} ; p<0,1+$

Note: Year effects controlled but not shown. 
A Theoretical Grounding and Test of the GEM model

Table 4 Perception of start-up skills, entrepreneurship education and training, and entrepreneurial activity in high-income countries (GEM 2000 - 2006 dataset)

\begin{tabular}{|c|c|c|c|c|c|c|c|}
\hline \multicolumn{8}{|c|}{ High-Income Countries (GDP per capita over 20 kUSD) } \\
\hline & Skill & TEA & TEA & HEA & HEA & rHEA & rHEA \\
\hline GDP per cap (ppp) & 2,97E-05 & $7,45 \mathrm{E}-06$ * & $-3,53 \mathrm{E}-07$ & $9,54 \mathrm{E}-07$ & $1,55 \mathrm{E}-07$ & $-1,82 \mathrm{E}-06$ & $-2,47 \mathrm{E}-06$ \\
\hline GDP per cap (squared) & $-1,89 \mathrm{E}-10$ & $-1,22 \mathrm{E}-10$ * & $-5,67 E-11$ & $-1,85 \mathrm{E}-11$ & $-9,79 \mathrm{E}-12$ & $1,04 \mathrm{E}-10$ & $8,38 \mathrm{E}-11$ \\
\hline GDP change & 0,0004 & $-0,0013$ & 0,0007 & $-0,0002$ & 0,0000 & 0,0009 & 0,0019 \\
\hline Population Growth & $-2,6403$ & $-0,2332$ & $-0,3003$ & $-0,0541$ & $-0,0270$ & $-0,3103$ & 0,3958 \\
\hline Estab. e-ship rate & $0,7137^{* *}$ & 0,1638 ** & 0,0442 & $0,0207+$ & 0,0144 & 0,0138 & 0,0697 \\
\hline Finance EFC & $-0,0223$ & 0,0032 & 0,0010 & 0,0012 & 0,0004 & 0,0136 & $-0,0003$ \\
\hline Policy EFC & $-0,0165$ & $-0,0028$ & 0,0030 & 0,0002 & 0,0004 & 0,0049 & $-0,0040$ \\
\hline Regulations EFC & 0,0113 & $0,0091+$ & 0,0030 & 0,0012 & 0,0009 & 0,0167 & 0,0321 \\
\hline Business services EFC & $-0,0454$ & $-0,0185$ * & $-0,0175$ * & $-0,0052 * *$ & $-0,0048 *$ & $-0,0535 *$ & $-0,0530+$ \\
\hline Market dynamism EFC & 0,0093 & $-0,0056$ & $-0,0076$ & $-0,0005$ & $-0,0016$ & 0,0013 & $-0,0123$ \\
\hline Physical infra EFC & 0,0331 & $-0,0054$ & 0,0042 & $-0,0012$ & $-0,0001$ & $-0,0146$ & $-0,0214$ \\
\hline Entrep culture EFC & $-0,0032$ & 0,0007 & 0,0102 & $-0,0015$ & $-0,0004$ & $-0,0207$ & $-0,0188$ \\
\hline Start-up skills & & & 0,0308 * & & $-0,0009$ & & $-0,0323$ \\
\hline Primary education EFC & $-0,0251$ & $-0,0144$ * & $-0,0163 *$ & $-0,0020$ & $-0,0038+$ & 0,0037 & $-0,0128$ \\
\hline Higher education EFC & $0,0784+$ & $0,0151 *$ & 0,0083 & $0,0039 *$ & 0,0052 * & 0,0253 & $0,0519 *$ \\
\hline R-sq (within) & 0,3302 & 0,3881 & 0,4513 & 0,2575 & 0,3097 & 0,1804 & 0,2276 \\
\hline Observations & 129 & 147 & 129 & 147 & 129 & 147 & 129 \\
\hline Groups & 27 & 27 & 27 & 27 & 27 & 27 & 27 \\
\hline Prob $>$ F & $0,000 * * *$ & $0,000 * * *$ & $0,000 * * *$ & $0,000 * * *$ & $0,000 * * *$ & $0,000 * * *$ & $0,000 * * *$ \\
\hline
\end{tabular}

Note: GLS coefficients; 2-tailed significances; $\mathrm{p}<0,001^{* * *} ; \mathrm{p}<0,01^{* *}$ : $\mathrm{p}<0,05^{*} ; \mathrm{p}<0,1+$

Note: Year effects controlled but not shown. 
Appendix 1 Items employed in the 2006 National Expert Survey

\begin{tabular}{|c|c|c|}
\hline EFC type & $\begin{array}{l}\text { Item } \\
\text { code }\end{array}$ & Item wording \\
\hline Finance EFC & $\mathrm{A} 01$ & $\begin{array}{l}\text { In my country, there is sufficient equity funding available for new } \\
\text { and growing firms. }\end{array}$ \\
\hline Finance EFC & A02 & $\begin{array}{l}\text { In my country, there is sufficient debt funding available for new and } \\
\text { growing firms. }\end{array}$ \\
\hline Finance EFC & A03 & $\begin{array}{l}\text { In my country, there are sufficient government subsidies available } \\
\text { for new and growing firms. }\end{array}$ \\
\hline Finance EFC & A04 & $\begin{array}{l}\text { In my country, there is sufficient funding available from private in- } \\
\text { dividuals (other than founders) for new and growing firms. }\end{array}$ \\
\hline Finance EFC & A05 & $\begin{array}{l}\text { In my country, there is sufficient venture capitalist funding available } \\
\text { for new and growing firms. }\end{array}$ \\
\hline Finance EFC & A06 & $\begin{array}{l}\text { In my country, there is sufficient funding available through initial } \\
\text { public offerings (IPOs) for new and growing firms. }\end{array}$ \\
\hline Policy EFC & B01 & $\begin{array}{l}\text { In my country, government policies (e.g., public procurement) con- } \\
\text { sistently favor new firms. }\end{array}$ \\
\hline Policy EFC & $\mathrm{B} 02$ & $\begin{array}{l}\text { In my country, the support for new and growing firms is a high pri- } \\
\text { ority for policy at the national government level. }\end{array}$ \\
\hline Policy EFC & B03 & $\begin{array}{l}\text { In my country, the support for new and growing firms is a high pri- } \\
\text { ority for policy at the local government level. }\end{array}$ \\
\hline Regulations EFC & B04 & $\begin{array}{l}\text { In my country, new firms can get most of the required permits and } \\
\text { licenses in about a week. }\end{array}$ \\
\hline Regulations EFC & B05 & $\begin{array}{l}\text { In my country, the amount of taxes is NOT a burden for new and } \\
\text { growing firms. }\end{array}$ \\
\hline Regulations EFC & B06 & $\begin{array}{l}\text { In my country, taxes and other government regulations are applied } \\
\text { to new and growing firms in a predictable and consistent way. }\end{array}$ \\
\hline Regulations EFC & B07 & $\begin{array}{l}\text { In my country, coping with government bureaucracy, regulations, } \\
\text { and licensing requirements it is not unduly difficult for new and } \\
\text { growing firms. }\end{array}$ \\
\hline Programs EFC & $\mathrm{C} 01$ & $\begin{array}{l}\text { In my country, a wide range of government assistance for new and } \\
\text { growing firms can be obtained through contact with a single agency. }\end{array}$ \\
\hline Programs EFC & $\mathrm{C02}$ & $\begin{array}{l}\text { In my country, science parks and business incubators provide effec- } \\
\text { tive support for new and growing firms. }\end{array}$ \\
\hline Programs EFC & $\mathrm{C03}$ & $\begin{array}{l}\text { In my country, there are an adequate number of government pro- } \\
\text { grams for new and growing businesses. }\end{array}$ \\
\hline Programs EFC & $\mathrm{C04}$ & $\begin{array}{l}\text { In my country, the people working for government agencies are } \\
\text { competent and effective in supporting new and growing firms. }\end{array}$ \\
\hline Programs EFC & $\mathrm{C05}$ & $\begin{array}{l}\text { In my country, almost anyone who needs help from a government } \\
\text { program for a new or growing business can find what they need. }\end{array}$ \\
\hline Programs EFC & $\mathrm{C06}$ & $\begin{array}{l}\text { In my country, government programs aimed at supporting new and } \\
\text { growing firms are effective. }\end{array}$ \\
\hline $\begin{array}{l}\text { Primary educa- } \\
\text { tion EFC }\end{array}$ & D01 & $\begin{array}{l}\text { In my country, teaching in primary and secondary education encour- } \\
\text { ages creativity, self-sufficiency, and personal initiative. }\end{array}$ \\
\hline
\end{tabular}


Appendix 1 Items employed in the 2006 National Expert Survey continued

\begin{tabular}{|c|c|c|}
\hline $\begin{array}{l}\text { Primary educa- } \\
\text { tion EFC }\end{array}$ & D02 & $\begin{array}{l}\text { In my country, teaching in primary and secondary education pro- } \\
\text { vides adequate instruction in market economic principles. }\end{array}$ \\
\hline $\begin{array}{l}\text { Primary educa- } \\
\text { tion EFC }\end{array}$ & D03 & $\begin{array}{l}\text { In my country, teaching in primary and secondary education pro- } \\
\text { vides adequate attention to entrepreneurship and new firm creation. }\end{array}$ \\
\hline $\begin{array}{l}\text { Higher Educa- } \\
\text { tion EFC }\end{array}$ & D04 & $\begin{array}{l}\text { In my country, colleges and universities provide good and adequate } \\
\text { preparation for starting up and growing new firms. }\end{array}$ \\
\hline $\begin{array}{l}\text { Higher Educa- } \\
\text { tion EFC }\end{array}$ & D05 & $\begin{array}{l}\text { In my country, the level of business and management education pro- } \\
\text { vide good and adequate preparation for starting up and growing new } \\
\text { firms. }\end{array}$ \\
\hline $\begin{array}{l}\text { Higher Educa- } \\
\text { tion EFC }\end{array}$ & D06 & $\begin{array}{l}\text { In my country, the vocational, professional, and continuing educa- } \\
\text { tion systems provide good and adequate preparation for starting up } \\
\text { and growing new firms. }\end{array}$ \\
\hline $\begin{array}{l}\text { R\&D transfer } \\
\text { EFC }\end{array}$ & E01 & $\begin{array}{l}\text { In my country, new technology, science, and other knowledge are } \\
\text { efficiently transferred from universities and public research centers } \\
\text { to new and growing firms. }\end{array}$ \\
\hline ransfer & E02 & $\begin{array}{l}\text { In my country, new and growing firms have just as much access to } \\
\text { new research and technology as large, established firms. }\end{array}$ \\
\hline $\begin{array}{l}\text { R\&D transfer } \\
\text { EFC }\end{array}$ & E03 & $\begin{array}{l}\text { In my country, new and growing firms can afford the latest technol- } \\
\text { ogy. }\end{array}$ \\
\hline $\begin{array}{l}\text { R\&D transfer } \\
\text { EFC }\end{array}$ & E04 & $\begin{array}{l}n \text { my country, there are adequate government subsidies for new and } \\
\text { rowing firms to acquire new technology. }\end{array}$ \\
\hline $\begin{array}{l}\text { R\&D transfer } \\
\text { EFC }\end{array}$ & E05 & $\begin{array}{l}\text { In my country, the science and technology base efficiently supports } \\
\text { the creation of world-class new technology-based ventures in at least } \\
\text { one area. }\end{array}$ \\
\hline $\begin{array}{l}\text { R\&D transfer } \\
\text { EFC }\end{array}$ & E06 & $\begin{array}{l}\text { In my country, there is good support available for engineers and sci- } \\
\text { entists to have their ideas commercialized through new and growing } \\
\text { firms. }\end{array}$ \\
\hline $\begin{array}{l}\text { Business services } \\
\text { EFC }\end{array}$ & F01 & $\begin{array}{l}\text { are enough subcontractors, suppliers, and con- } \\
\mathrm{N} \text { and growing firms. }\end{array}$ \\
\hline $\begin{array}{l}\text { Business services } \\
\text { EFC }\end{array}$ & F02 & $\begin{array}{l}\text { my country, new and growing firms can afford the cost of using } \\
\text { ubcontractors, suppliers, and consultants. }\end{array}$ \\
\hline $\begin{array}{l}\text { Business services } \\
\text { EFC }\end{array}$ & F03 & $\begin{array}{l}\text { In my country, it is easy for new and growing firms to get good sub- } \\
\text { contractors, suppliers, and consultants. }\end{array}$ \\
\hline $\begin{array}{l}\text { Business services } \\
\text { EFC }\end{array}$ & F04 & $\begin{array}{l}\text { In my country, it is easy for new and growing firms to get good, pro- } \\
\text { fessional legal and accounting services. }\end{array}$ \\
\hline $\begin{array}{l}\text { Business services } \\
\text { EFC }\end{array}$ & F05 & $\begin{array}{l}\text { In my country, it is easy for new and growing firms to get good } \\
\text { banking services (checking accounts, foreign exchange transactions, } \\
\text { letters of credit, and the like). }\end{array}$ \\
\hline $\begin{array}{l}\text { Mark } \\
\text { mism }\end{array}$ & G01 & $\begin{array}{l}\text { country, the markets for consumer goods and services change } \\
\text { atically from year to year. }\end{array}$ \\
\hline
\end{tabular}

Appendix 1 Items employed in the 2006 National Expert Survey continued. 


\begin{tabular}{|c|c|c|}
\hline $\begin{array}{l}\text { Market dyna- } \\
\text { mism EFC }\end{array}$ & G02 & $\begin{array}{l}\text { In my country, the markets for business-to-business goods and ser- } \\
\text { vices change dramatically from year to year. }\end{array}$ \\
\hline $\begin{array}{l}\text { Market openness } \\
\text { EFC }\end{array}$ & G03 & In my country, new and growing firms can easily enter new markets. \\
\hline $\begin{array}{l}\text { Market openness } \\
\text { EFC }\end{array}$ & G04 & $\begin{array}{l}n \text { my country, the new and growing firms can afford the cost of } \\
\text { narket entry. }\end{array}$ \\
\hline $\begin{array}{l}\text { Market openness } \\
\text { EFC }\end{array}$ & G05 & $\begin{array}{l}\text { In my country, new and growing firms can enter markets without } \\
\text { being unfairly blocked by established firms. }\end{array}$ \\
\hline $\begin{array}{l}\text { Market openness } \\
\text { EFC }\end{array}$ & G06 & $\begin{array}{l}\text { In my country, the anti-trust legislation is effective and well en- } \\
\text { forced. }\end{array}$ \\
\hline $\begin{array}{l}\text { Physical infra } \\
\text { EFC }\end{array}$ & $\mathrm{H} 01$ & $\begin{array}{l}\text { In my country, the physical infrastructure (roads, utilities, communi- } \\
\text { cations, waste disposal) provides good support for new and growing } \\
\text { firms. }\end{array}$ \\
\hline $\begin{array}{l}\text { Physical infra } \\
\text { EFC }\end{array}$ & $\mathrm{H} 02$ & $\begin{array}{l}\text { country, it is not too expensive for a new or growing firm to } \\
\text { od access to communications (phone, Internet, etc.). }\end{array}$ \\
\hline $\begin{array}{l}\text { Physical infra } \\
\text { EFC }\end{array}$ & H03 & $\begin{array}{l}\text { In my country, a new or growing firm can get } \\
\text { munications (telephone, internet, etc.) in about a }\end{array}$ \\
\hline $\begin{array}{l}\text { Physical infra } \\
\text { EFC }\end{array}$ & $\mathrm{H} 04$ & $\begin{array}{l}\text { In my country, new and growing firms can afford the cost of basic } \\
\text { utilities (gas, water, electricity, sewer). }\end{array}$ \\
\hline $\begin{array}{l}\text { Physical infra } \\
\text { EFC }\end{array}$ & H05 & $\begin{array}{l}\text { In my country, new or growing firms can get good access to utilities } \\
\text { (gas, water, electricity, sewer) in about a month. }\end{array}$ \\
\hline $\begin{array}{l}\text { Entrep culture } \\
\text { EFC }\end{array}$ & I01 & $\begin{array}{l}\text { In my country, the national culture is highly supportive of individual } \\
\text { success achieved through own personal efforts. }\end{array}$ \\
\hline $\begin{array}{l}\text { Entrep culture } \\
\text { EFC }\end{array}$ & $\mathrm{I} 02$ & $\begin{array}{l}\text { In my country, the national culture emphasizes self-sufficiency, } \\
\text { autonomy, and personal initiative. }\end{array}$ \\
\hline $\begin{array}{l}\text { Entrep culture } \\
\text { EFC }\end{array}$ & $\mathrm{I} 03$ & $\begin{array}{l}\text { In my country, the national culture encourages entrepreneurial risk- } \\
\text { taking. }\end{array}$ \\
\hline $\begin{array}{l}\text { Entrep culture } \\
\text { EFC }\end{array}$ & $\mathrm{I} 04$ & $\begin{array}{l}\text { In my country, the national culture encourages creativity and inno- } \\
\text { vativeness. }\end{array}$ \\
\hline $\begin{array}{l}\text { Entrep culture } \\
\text { EFC }\end{array}$ & $\mathrm{I} 05$ & $\begin{array}{l}\text { In my country, the national culture emphasizes the responsibility } \\
\text { that the individual (rather than the collective) has in managing his or } \\
\text { her own life. }\end{array}$ \\
\hline
\end{tabular}

